\title{
OIL, ENVIRONMENTAL POLLUTION AND LIFE EXPECTANCY IN NIGERIA
}

\author{
AgBanike, T. F. ${ }^{1 *}$ - NWANi, C. ${ }^{1}$ - UwaZIE, U. I. ${ }^{2}-$ UMA, K. E. ${ }^{1}-$ ANOCHIWA, L. I. ${ }^{1}$ - IGBeri, C. \\ O. ${ }^{3}$ - ENYOGHASIM, M. O. ${ }^{1}$ - UWAJUMOGU, N. R. ${ }^{1}$ - ONWUKA, K. O. ${ }^{1}-$ OgBONNAYA, I. O. ${ }^{1}$ \\ ${ }^{1}$ Department of Economics and Development Studies, Alex Ekwueme Federal University, \\ Ndufu-Alike, Ebonyi Sate, Nigeria \\ (e-mails:nwanichinaza@gmail.com-C.Nwani; kaluskyebng@yahoo.com-K.E.Uma; \\ lanochiwa@yahoo.com-L.I. Anochiwa; mic_martserve@yahoo.com-M.O.Enyoghasim; \\ ketchyus@yahoo.com-N.R.Uwajumogu; odulukwe@yahoo.com-K.O.Onwuka; \\ ioogbons@yahoo.com-I.O.Ogbonnaya) \\ ${ }^{2}$ Department of Economics, Michael Okpara University of Agriculture, Umudike, Abia \\ State, Nigeria \\ (e-mail:ui.uwazie@yahoo.com) \\ ${ }^{3}$ Department of Agriculture (Agricultural Economics and Extension Programme), \\ Alex Ekwueme Federal University, Ndufu-Alike, Ebonyi Sate, Nigeria \\ (e-mail: igberitina@yahoo.com; Christiana.igberi@funai.edu.ng) \\ *Corresponding author \\ e-mail: tobechi_agbanike@yahoo.co.uk,tobechi.agbanike@funai.edu.ng;phone:+234-90- \\ $6035-4318$
}

(Received $4^{\text {th }}$ Apr 2019; accepted $13^{\text {th }}$ Jun 2019)

\begin{abstract}
This study used the autoregressive distributed lag (ARDL) bounds testing approach to cointegration to examine the dynamic relationship between environmental pollution and life expectancy in Nigeria over the period 1971 to 2014 incorporating the role of the oil sector. The ARDL estimates suggest that while oil export provides the revenue required to improve life expectancy in the country, it also generates economic conditions that accelerate environmental pollution in the country. The results show that the impact of carbon dioxide $\left(\mathrm{CO}_{2}\right)$ emissions on life expectancy in Nigeria is negative and stronger in the long run. To further the understanding of the impacts of oil production activities and $\mathrm{CO}_{2}$ emissions on life expectancy in Nigeria, gender differences in life expectancy were considered. The results highlight the urgent need for health policy measures in Nigeria to incorporate effective mitigation and adaptation strategies to reduce the impact of the increasing role of the oil sector on health condition, wellbeing of the people and the overall goal of improving life expectancy in Nigeria.
\end{abstract}

Keywords: export receipts, health policy, carbon dioxide $\left(\mathrm{CO}_{2}\right)$ emissions, greenhouse gases (GHG), gas flaring

\section{Introduction}

Life expectancy, a measure of the length of life expected to be lived by an individual at birth is considered an important indicator of a nation's health condition and individual's wellbeing. Since individuals make a nation, improving life expectancy is a very important and necessary condition needed to achieve long-term sustainable economic development (Barlow and Vissandjée, 1999; Alam et al., 2016; Shahbaz et al., 2016). Recent studies show that life expectancy of a nation is reflected in the social, economic, demographic and environmental conditions (see Hertz et al., 1994; Barlow and Vissandjée, 1999; Pautrel, 2009; Bergh and Nilsson, 2010; Mariani et al., 2010; Qureshi et al., 2015; Sede and Ohemeng, 2015; Alam et al., 2016; Kim and Kim, 2016; 
Shahbaz et al., 2016; Lu et al., 2017; Wu, 2017; Abbas and Awan, 2018; Bader and Ganguli, 2019). Therefore, the impacts of various economic, social and environmental factors on life expectancy for a given country have become a very important issue among policy makers. However, despite the increasing attention of studies on identifying the determinants of life expectancy, there is still no empirical study that examines how oil sector activities and the resultant environmental pollution impact on life expectancy in Nigeria. Hence, this study aims to fill this identified gap in the existing literature by investigating the dynamic relationship between oil sector activities, environmental pollution and life expectancy in Nigeria.

The threat of oil sector activities on environmental quality in Nigeria has been widely recognized and cannot be overlooked (see Ologunorisa, 2001; Ugochukwu and Ertel, 2008; Audu et al., 2016). A deteriorating environment is responsible for many adverse effects on health and well-being (Tai et al., 2015; Chaabouni et al., 2016; Marsh et al., 2016; Perera, 2018). Policymakers in Nigeria are facing pressure in ensuring sustainable health condition and wellbeing of the people. The main reason being that social, economic and environmental conditions that determine the quality of health care services and individual's wellbeing depend significantly on oil sector activities as illustrated in Figure 1. On one hand, fiscal spending that determines health care expenditure, quality of education, availability of employment opportunities and sanitation facilities and access to portable drinking water depends solely on the volume of crude oil receipts, which accounts for about $95 \%$ of export earnings in Nigeria. Higher volume of crude oil export could therefore be interpreted to suggest more economic resources for better health care services. On the other hand, the exploration and production activities of the oil sector in Nigeria have resulted in environmental pollution, by way of relentless flaring and venting of gas to the environment (Audu et al., 2016). There is a global acceptance that the rising level of greenhouse gases in the atmosphere is the single greatest public health threat of the 21 st century. Extreme temperature and weather conditions such as heat wave, storm, drought, and flood caused by the absorption of some of the radiation emitted from the earth by greenhouse gases in the atmosphere are considered by experts as one of the major direct risks to human health (Bezirtzoglou et al., 2011; Franchini and Mannucci, 2015; Wu et al., 2016; Liang and Gong, 2017). For instance, some health issues prevalent in Nigeria including respiratory and cardiovascular diseases, diarrheal diseases in children and mosquitoborne diseases such as malaria are among diseases identified to be most sensitive to temperature and climate conditions (see Bezirtzoglou et al., 2011). With this in mind, the need to understand and control the potential consequences of the activities of the oil sector on health conditions and wellbeing of Nigerians cannot be overemphasized.

Although life expectancy in Nigeria has improved over the years, Figure 2 shows that it is still below the average life expectancy in Low income countries and SubSaharan African economies. Looking at the comparative figures, the life expectancy in South Africa and Ghana is higher with over nine years in 2014. In recognition of the urgent need to improve life expectancy in Nigeria, health policy makers have set policy targets and a number of policy measures have been taken in this direction including the primary health care service intended to enhance access to quality health care, the commercialization policy designed to inject some measures of efficiency into public hospital management and the National Health Insurance Scheme designed to mitigate the cost of access to quality health care (Sede and Ohemeng, 2015). In the light of the above discussion, this study aims at offering some policy measures to the attainment of 
health policy targets by examining the dynamic relationship between oil sector activities, environmental pollution (as proxied by $\mathrm{CO}_{2}$ emissions) and life expectancy in Nigeria. This is achieved by employing the auto-regressive distributed lag (ARDL) bounds testing approach for cointegration analysis to uncover the long-run and short-run impacts of the variables including (i) the impact of oil resource as source of revenue on environmental quality and life expectancy in Nigeria (ii) the impact of crude oil production and exploration on life expectancy in Nigeria, and (iii) the impact of $\mathrm{CO}_{2}$ emissions on life expectancy in Nigeria.

The remainder of this study is structured as follows: Section 2 presents the data and methodology of the study. Section 3 presents the empirical results. In section 4 the empirical results are discussed and some policy implications highlighted. Finally, section 5 offers some concluding remarks.

\section{Materials and methods}

\section{Definition of variables and data description}

This study uses annual data covering the period from 1971 to 2014 to examine the dynamic relationship between oil sector activities, environmental pollution and life expectancy in Nigeria. The average daily crude oil production is used to capture oil production effect while the value of oil exports is used to capture oil income effect of the activities of the oil sector. Carbon dioxide $\left(\mathrm{CO}_{2}\right)$ emissions in metric tons per capita is used to measure environmental pollution. Life expectancy is measured as the average number of years of life of the total population (female and male), male population and female population. List of all the variables and data sources are presented in Table 1.

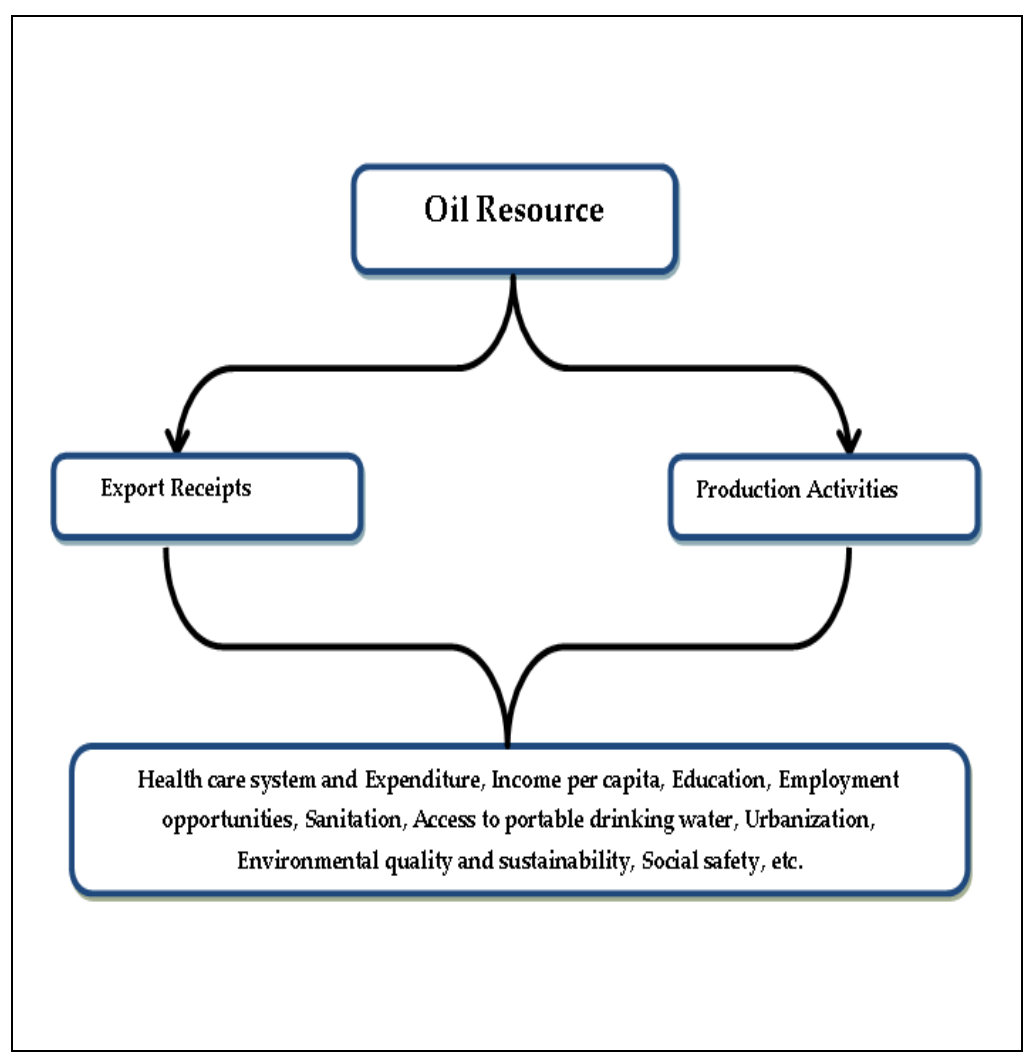

Figure 1. Oil resource and health services 


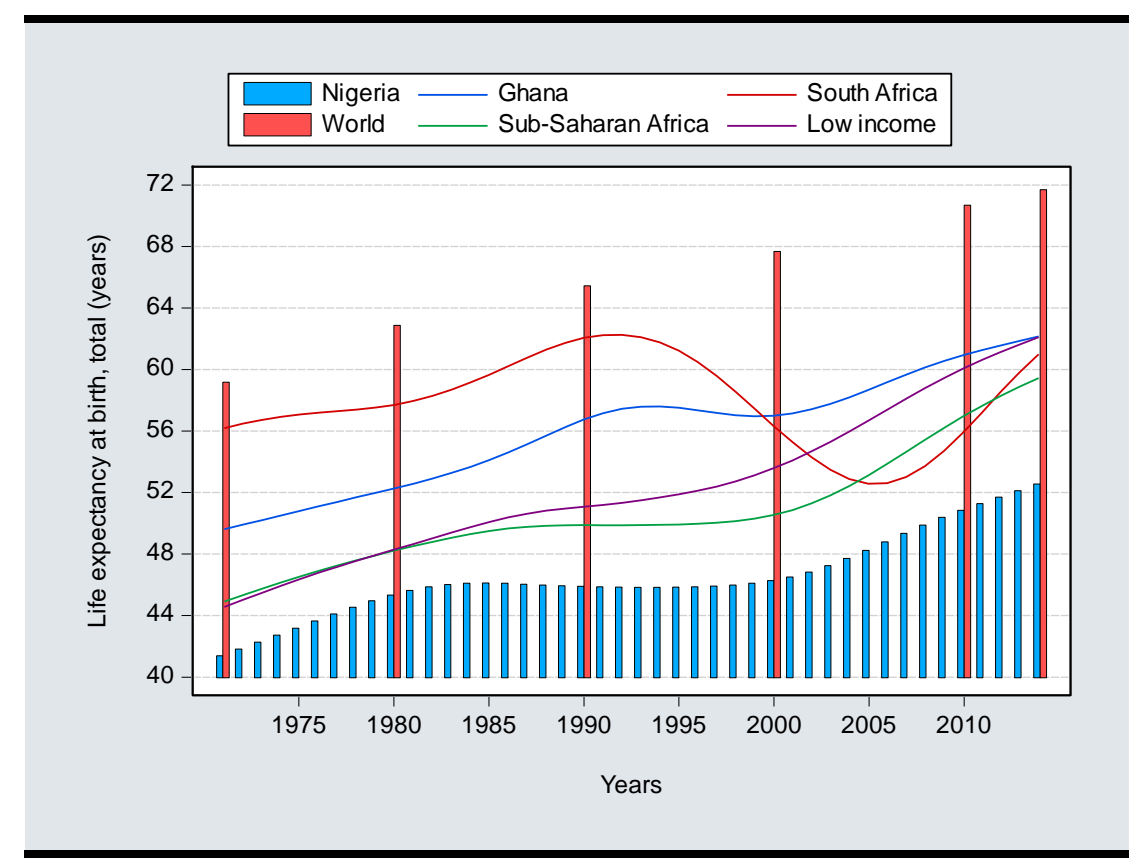

Figure 2. Life expectancy at birth, total (years). (Data source: World Development Indicators, World Bank)

Table 1. Definition of variables and data description

\begin{tabular}{c|c|c}
\hline Variable & Definition & Source \\
\hline $\mathrm{CO} 2$ & $\mathrm{CO}_{2}$ emissions (metric tons per capita) & World Development Indicators Database, World Bank \\
LifE & Life Expectancy at Birth, Total (years) & World Development Indicators Database, World Bank \\
LifEM & Life Expectancy at Birth, Male (years) & World Development Indicators Database, World Bank \\
LifEF & Life Expectancy at Birth, Female (years) & World Development Indicators Database, World Bank \\
Rgdpc & GDP per capita (constant 2010 US\$) & World Development Indicators Database, World Bank \\
VPet & Values of petroleum exports (m \$) & OPEC Annual Statistical Bulletin 2018 Online \\
Crdoilp & Daily crude oil production (average) & OPEC Annual Statistical Bulletin 2018 Online \\
Pcrd & Private credit by deposit money banks to GDP $(\%)$ & Global Financial Development Indicators, World Bank \\
Dcrd & Domestic credit to private sector (\% of GDP) & World Development Indicators Database, World Bank \\
Popgrt & Population Growth (Annual \%) & World Development Indicators Database, World Bank \\
Infrt & Inflation, consumer prices (annual \%) & World Development Indicators Database, World Bank \\
Trd & Trade (Export + Import \% of GDP) & World Development Indicators Database, World Bank \\
\hline
\end{tabular}

\section{Empirical model and estimation method}

This study empirically examines three log-linear models to uncover the relationship between oil sector activities, environmental pollution and life expectancy in Nigeria over the period 1971-2014. Model 1 and Model 2 examine the impact of oil sector activities and $\mathrm{CO} 2$ emissions on life expectancy in Nigeria while Model 3 examines the role of oil sector activities in explaining environmental pollution $\left(\mathrm{CO}_{2}\right.$ emissions $)$ in Nigeria. In Model 1 specified in Equation 1 oil sector activity is captured using value of petroleum exports per capita (oil income effect) while in Model 2 specified in Equation 2 oil sector activity is captured using the average daily crude oil production (oil production effect). Figure 3 summarises the three causal relationships examined in this empirical study. 


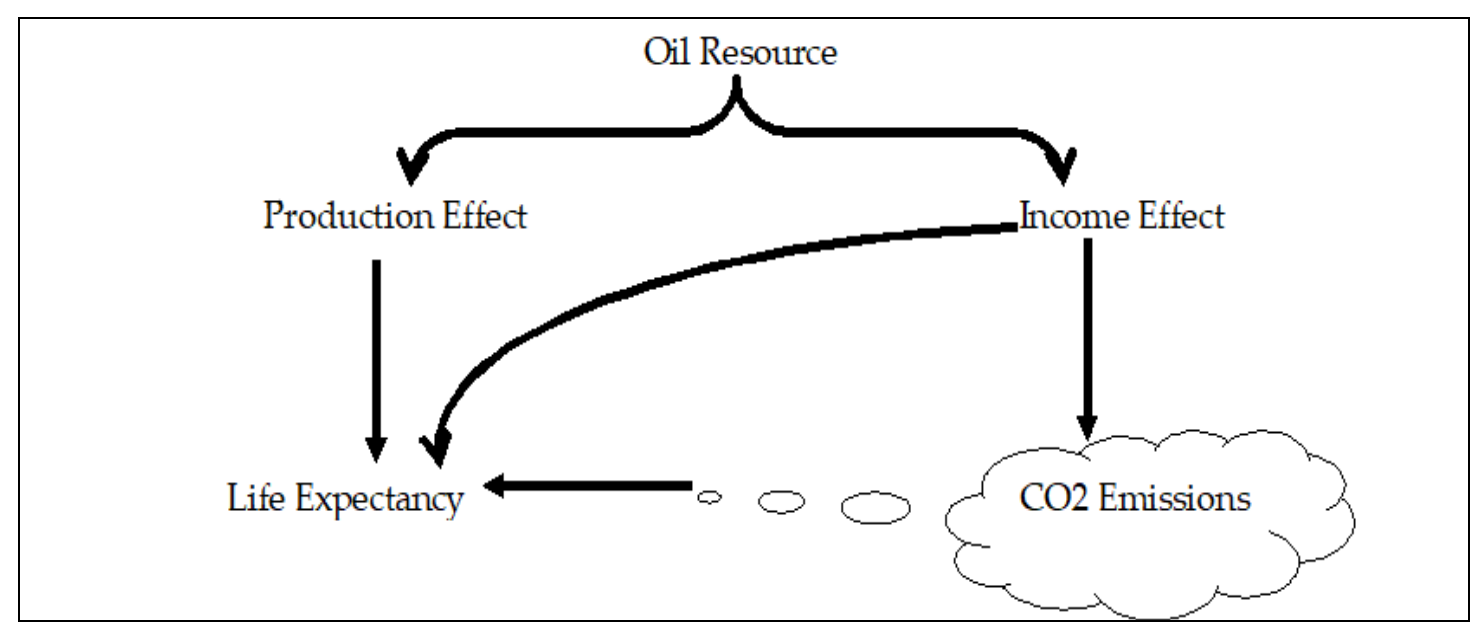

Figure 3. Hypothesized relationship between oil sector activities, $\mathrm{CO}_{2}$ emissions and life expectancy in Nigeria

\section{Model 1}

$$
\operatorname{lnLif}=\alpha_{0}+\alpha_{1} \operatorname{lnRgdpc}+\alpha_{2} \ln \mathrm{CO} 2+\alpha_{3} \ln \mathrm{Pvet}+\alpha_{4} \ln \text { Contrl } 1+\alpha_{5} \text { Contrl } 2+\alpha_{5} \text { Contrl } 3+e_{t}
$$

Model 2

$$
\operatorname{lnlif}=\beta_{0}+\beta_{1} \ln R g d p c+\beta_{2} \ln C O 2+\beta_{3} \ln \text { Crdoilp }+\beta_{4} \ln \text { Contrl } 1+\beta_{5} \text { Contrl } 2+\beta_{6} \text { Contrl } 3+e_{t}
$$

\section{Model 3}

$$
\operatorname{lnCO} 2=\pi_{0}+\pi_{1} \ln R g d p c+\pi_{2} \operatorname{lnlif}+\pi_{3} \ln \mathrm{Pvet}+\pi_{4} \ln \text { Contrl } 1+\pi_{5} \text { Contrl } 2+\pi_{5} \text { Contrl3 }+e_{t}
$$

lnLif represents life expectancy, measured as the average number of years of life of the total population (female and male) $\ln L i f E$, male population $\ln L i f E M$ and female population $\ln L i f E F$. $\ln R g d p c, \operatorname{lnCO} 2, \ln$ Pvet and $\ln$ Crdoilp are as defined in Table 1. lnContrl 1 , lnContrl 2 and lnContrl 3 are used to control for the influence of other factors considered important in this empirical analysis. These factors include international trade, financial development and population growth. $e_{t}$ is the error term.

Following Murthy and Okunade (2016), Shahbaz et al. (2016) and Abbas and Awan (2018) this study employs the autoregressive distributed lag (ARDL) Bounds testing approach to co-integration proposed by Pesaran et al. (2001) to investigate the log-linear empirical model specified in Equations 1, 2 and 3. The ARDL approach offers some desirable statistical advantages over other co-integration techniques. While other cointegration techniques require all the variables to be integrated of the same order, ARDL test procedure provides valid results whether the variables are I(0) or I(1) or mutually co-integrated, captures both short-run dynamics and long-run equilibrium adjustment of the studied process and provides very efficient and consistent test results in small and large sample sizes (see Pesaran et al., 2001). The implementation of the ARDL test for Equations 1, 2 and 3 involves the estimation of the following models: 
ARDL estimation for Model 1:

$$
\begin{aligned}
& \Delta \operatorname{lnlif}_{t}=a_{0}+\sum_{i=1}^{n} a_{1 i} \Delta \operatorname{slnlif}_{t-i}+\sum_{i=0}^{n} a_{2 i} \Delta \operatorname{lnRgdpc_{1t-i}}+\sum_{i=0}^{n} a_{3 i} \Delta \operatorname{snco} 2_{2 t-i}+\sum_{i=0}^{n} a_{4 i} \Delta \operatorname{slnVpet}_{3 t-i} \\
& +\sum_{i=0}^{n} a_{5 i} \Delta \operatorname{snCtrl} 1_{4_{t-i}}+\sum_{i=0}^{n} a_{6 i} \Delta \operatorname{slnCtrl} 2_{5_{t-i}}+\sum_{i=0}^{n} a_{7 i} \operatorname{sinCtrl} 3_{6 t-i}+a_{8} \operatorname{lnlif} f_{t-1} \\
& +a_{9} \ln R g d p c_{t-1}+a_{10} \operatorname{lnCO} 2_{t-1}+a_{11} \operatorname{lnVpet}_{t-1}+a_{12} \operatorname{lnCtrl1_{t-1}} \\
& +a_{13} \ln C t r l 2_{t-1}+a_{14} \operatorname{lnCtrl3}{ }_{t-1} \\
& +\varepsilon_{t}
\end{aligned}
$$

ARDL estimation for Model 2:

$$
\begin{aligned}
& \Delta \operatorname{lnlif}_{t}=\beta_{0}+\sum_{i=1}^{n} \beta_{1 i} \Delta \operatorname{slnlif}_{t-i}+\sum_{i=0}^{n} \beta_{2 i} \Delta \operatorname{lnRgdpc_{1-i}}+\sum_{i=0}^{n} \beta_{3 i} \Delta \operatorname{snCO}_{2_{t-i}}+\sum_{i=0}^{n} \beta_{4 i} \Delta \operatorname{lnCrdoilp}_{3_{t-i}} \\
& +\sum_{i=0}^{n} \beta_{5 i} \Delta \operatorname{lnCtrl1_{4}t-i}+\sum_{i=0}^{n} \beta_{6 i} \Delta \operatorname{snCtrl} 2_{5_{t-i}}+\sum_{i=0}^{n} \beta \Delta \operatorname{lnCtrl3_{6t-i}}+\beta_{8} \operatorname{lnlif}_{t-1} \\
& +\beta_{9} \operatorname{lnRgdpc_{t-1}}+\beta_{10} \operatorname{lnCO}_{t-1}+\beta_{11} \text { lnCrdoilp }_{t-1}+\beta_{12} \operatorname{lnCtrl~}_{t-1} \\
& +\beta_{13} \operatorname{lnCtrl2} t-1+\beta_{14} \operatorname{lnCtrl3_{t-1}} \\
& +\varepsilon_{t}
\end{aligned}
$$

ARDL estimation for Model 3:

$$
\begin{aligned}
& \Delta \operatorname{lnCO} 2_{t}=\pi_{0}+\sum_{i=1}^{n} \pi_{1 i} \Delta \operatorname{lnCO} 2_{t-i}+\sum_{i=0}^{n} \pi_{2 i} \Delta \operatorname{lnRgdpc}_{1_{t-i}}+\sum_{i=0}^{n} \pi_{3 i} \Delta \operatorname{sllif}_{2 t-i}+\sum_{i=0}^{n} \pi_{4 i} \Delta \operatorname{lnVpet}_{3 t-i} \\
& +\sum_{i=0}^{n} \pi_{5 i} \Delta \operatorname{slnCtrl1_{4}}{ }_{4-i}+\sum_{i=0}^{n} \pi_{6 i} \Delta \operatorname{lnCtrl2} 2_{t-i}+\sum_{i=0}^{n} \pi_{7 i} \Delta \operatorname{lnCtrl3_{6t-i}}+\pi_{8} \operatorname{lnCO} 2_{t-1}
\end{aligned}
$$

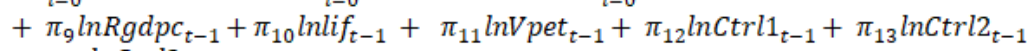

$$
\begin{aligned}
& +\pi_{14} \ln C \operatorname{trl} 3_{t-1} \\
& +\varepsilon_{t}
\end{aligned}
$$

where $\Delta$ is the difference operator while $\varepsilon_{t}$ is white noise error term. The following hypotheses are tested to investigate the existence of co-integration among the variables: the null hypothesis of no cointegration among the variables in Equation 4 is given as $\left(H_{0}: a_{8}=a_{9}=a_{10}=a_{11}=a_{12}=a_{13}=a_{14}=0\right)$ examined against the alternative hypothesis $\left(H_{1}: a_{8} \neq a_{9} \neq a_{10} \neq a_{11} \neq a_{12} \neq a_{13} \neq a_{14} \neq 0\right)$. In Equation 5 the null hypothesis of no cointegration among the variables is $\left(H_{0}: \beta_{8}=\beta_{9}=\beta_{10}=\beta_{11}=\beta_{12}=\beta_{13}=\beta_{14}=0\right)$ against the alternative hypothesis $\left(H_{1}: \beta_{8} \neq \beta_{9} \neq \beta_{10} \neq \beta_{11} \neq \beta_{12} \neq \beta_{13} \neq \beta_{14} \neq 0\right)$. In Equation 6 the null hypothesis of no cointegration among the variables is $\left(H_{0}: \pi_{8}=\pi_{9}=\pi_{10}=\pi_{11}=\pi_{12}=\pi_{13}=\pi_{14}=0\right)$ against the alternative hypothesis $\left(H_{1}: \pi_{8} \neq \pi_{9} \neq \pi_{10} \neq \pi_{11} \neq \pi_{12} \neq \pi_{13} \neq \pi_{14} \neq 0\right.$ ). The decision to reject or accept $H_{o}$ (no cointegration among the variables) is based on the following conditions: if the calculated F-statistics is greater than the upper critical bound, then $H_{o}$ is rejected and the variables are co-integrated, if the calculated F-statistics is less than the lower bound, then $H_{o}$ is accepted and the variables are not co-integrated, but if the calculated F-statistics remains between the lower and upper critical bounds then the decision is inconclusive (Pesaran et al., 2001).

After testing for cointegration among the variables, the long-run coefficients of the variables are then estimated. The existence of cointegration between the variables implies that causality exist in at least one direction. The error correction model for the estimation of the short run relationships is specified as: 


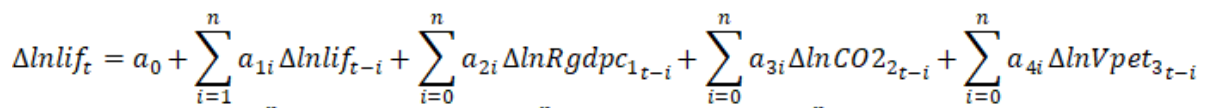

$$
\begin{aligned}
& +\sum_{i=0}^{n} a_{5 i} \Delta \operatorname{lnCtrl1_{4}} 4_{t-i}+\sum_{i=0}^{n} a_{6 i} \Delta \operatorname{lnCtrl} 2_{5_{t-i}}+\sum_{i=0}^{n} a_{7 i} \Delta \operatorname{lnCtrl3_{6t-i}}+\lambda_{1} E C M_{t-1} \\
& +u_{2 t} \\
& \text { (7) }
\end{aligned}
$$

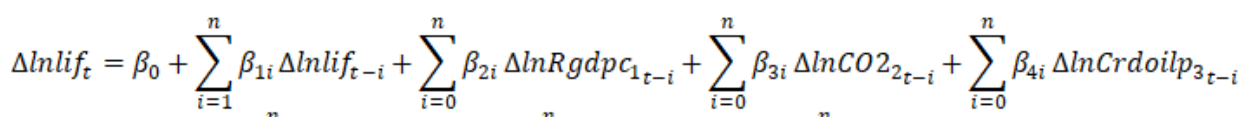

$$
\begin{aligned}
& +\sum_{i=0}^{n} \beta_{5 i} \Delta \operatorname{sinCtrl1_{4t-i}}+\sum_{i=0}^{n} \beta_{6 i} \Delta \operatorname{slnCtrl2_{5t-i}}+\sum_{i=0}^{n} \beta \Delta \operatorname{lnCtrl3_{6t-i}}+\lambda_{2} E C M_{t-1} \\
& +u_{2 t} \\
& \text { (8) }
\end{aligned}
$$

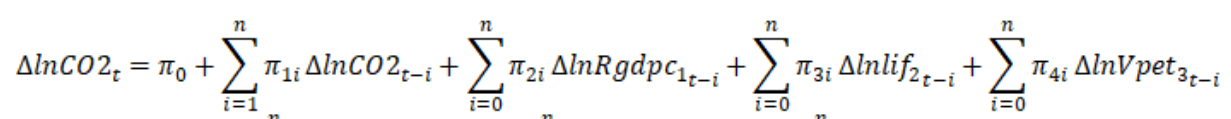

$$
\begin{aligned}
& +\sum_{i=0}^{n} \pi_{5 i} \Delta \operatorname{lnCtrl1_{4}}{ }_{t-i}+\sum_{i=0}^{n} \pi_{6 i} \Delta \operatorname{lnCtrl2_{5}} 5_{t-i}+\sum_{i=0}^{n} \pi_{7 i} \Delta \operatorname{lnCtrl3_{6t-i}}+\lambda_{3} \text { ECM }_{t-1} \\
& +u_{3 t}
\end{aligned}
$$

$E C M_{t-1}$ is the error correction term obtained from the cointegration model. The error correction coefficients $\left(\lambda_{1}, \lambda_{2}\right.$ and $\left.\lambda_{3}\right)$ indicate the rate at which the cointegration models correct previous period disequilibrium or speed of adjustment to restore the long-run equilibrium relationship. A negative and significant $E C M_{t-1}$ coefficient implies that any short term movement between the dependent and explanatory variables will converge back to the long-run relationship.

This study implements the following diagnostic tests to ensure the acceptability of the empirical models: Breusch-Godfrey serial correlation LM test, ARCH test for heteroscedasticity, Jarque-Bera normality test and Ramsey RESET test for functional form. The stability of the long-run coefficients together with the short-run dynamics are tested using the cumulative sum of recursive residuals (CUSUM) and the cumulative sum of squares of recursive residuals (CUSUMSQ) tests.

\section{Results}

Figure 4 displays plots of the data series of the variables of interest. The figure shows that life expectancy in Nigeria improved from 41.4 years in 1971 to 52.5 years in 2014. $\mathrm{CO}_{2}$ emissions which increased from 0.56 metric tons per capita in 1971 to 1.01 in 1974 decreased to 0.54 metric tons per capita in 2014. Interestingly daily crude oil production which increased from 1531.20 thousand barrels in 1971 to 2255.0 thousand in 1974 also decreased to 1807.05 thousand barrels in 2014. In the light of the observed movements in these series, it would be of great interest for health policy making to examine the dynamic relationship between oil sector activities, environmental pollution (as proxied by $\mathrm{CO}_{2}$ emissions) and life expectancy in Nigeria. This is achieved by employing the auto-regressive distributed lag (ARDL) bounds testing approach for cointegration analysis to uncover the long-run and short-run impacts of the variables including the impact of oil resource as source of revenue on environmental quality and life expectancy in Nigeria, the impact of crude oil production and exploration on life expectancy in Nigeria, and the impact of $\mathrm{CO}_{2}$ emissions on life expectancy in Nigeria. 


\section{Unit root tests}

The ARDL-bounds cointegration testing approach allows variables to be integrated of different orders $[\mathrm{I}(0)$ and $\mathrm{I}(1)]$, but does not require any of the variables to be integrated of order $2[\mathrm{I}(2)]$ (see Pesaran et al., 2001). It is therefore essential to examine the stationarity of the variables to ensure that none of the variables is integrated of order $2[\mathrm{I}(2)]$. To determine the order of integration of the variables, the Augmented Dickey Fuller test for unit root is implemented. The results in Table 2 show that inflation rate ( InInfr) is integrated of order zero, I(0) while other variables are integrated of order one I(1). In the presence of structural breaks however, the Augmented Dickey Fuller test and other conventional unit root tests are known to provide biased results because of their low explanatory strength to reject the null hypothesis of unit root. This is because these unit root tests do not incorporate information about structural break dates emanating from structural changes (Perron, 2006). To overcome this condition, modified augmented Dickey-Fuller test that detects unknown single structural break in a series is employed (see Vogelsang and Perron, 1998). The innovational outlier (IO) model which assumes that the break occurs gradually, with the breaks following the same dynamic path as the innovations is implemented. The results in Table 2 show a structural break in all the series. For life expectancy (lnlifE), a structural break is found in the series in 1997. For CO2 emissions, a structural break exists in 1986. These results give indication that the economy has observed significant policy shocks at the selected break dates. The stationary properties show that none of the variables is integrated at second difference $[\mathrm{I}(2)]$. The integration of the variables at $\mathrm{I}(0)$ and $\mathrm{I}(1)$ makes ARDL the preferred approach in this empirical analysis.

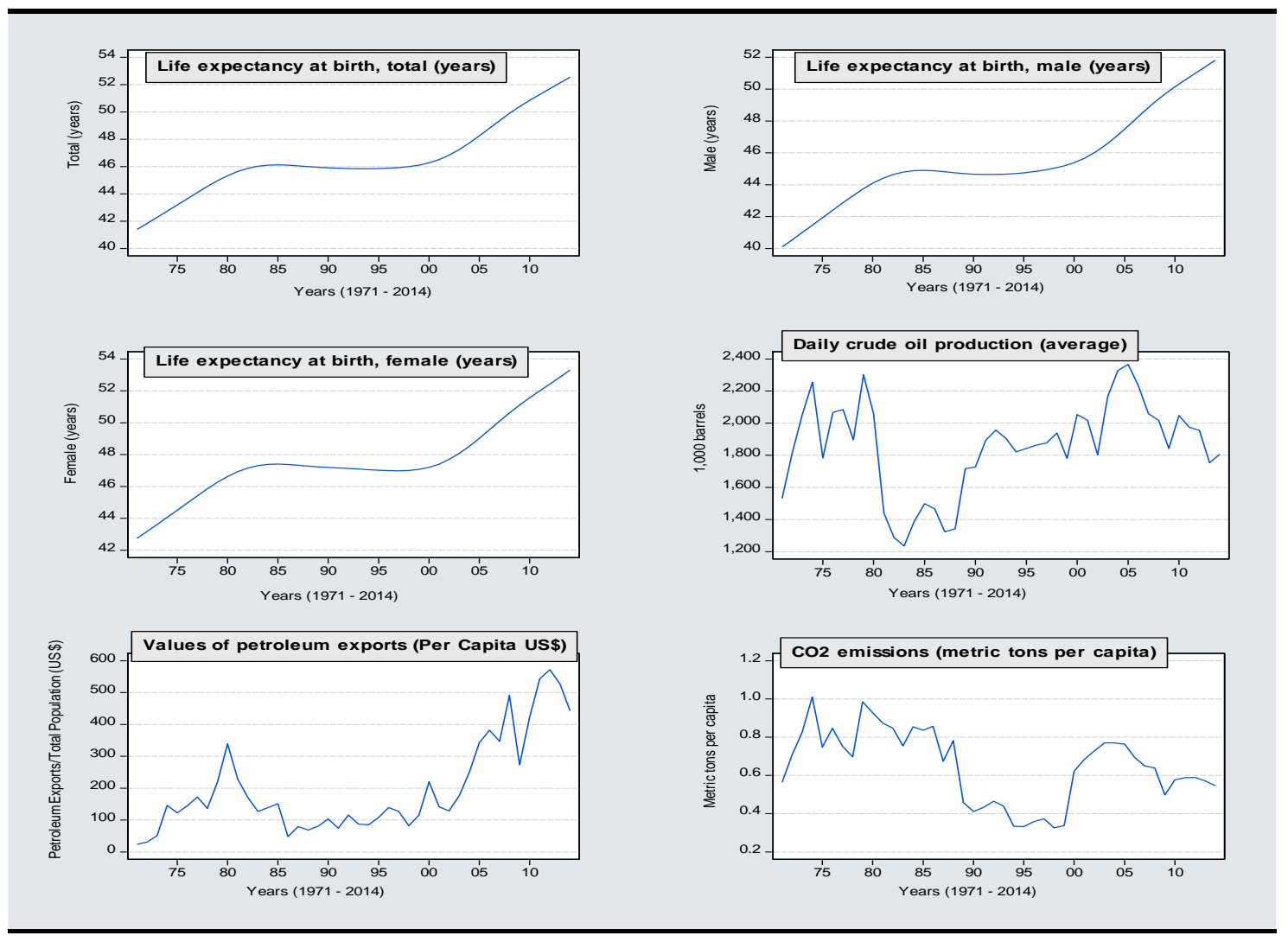

Figure 4. Plots of the data series of the variables of interest 
Table 2. Unit root test results

\begin{tabular}{|c|c|c|c|c|c|c|c|}
\hline & \multicolumn{2}{|c|}{ Augmented Dickey Fuller } & \multicolumn{4}{|c|}{ Modified augmented Dickey Fuller test with structural break } & \multirow{3}{*}{ Result } \\
\hline & \multirow{2}{*}{$\begin{array}{c}\text { Levels I (0) } \\
\text { t-statistic } \\
\end{array}$} & \multirow{2}{*}{\begin{tabular}{|c|} 
First difference I(1) \\
t-statistic \\
\end{tabular}} & \multicolumn{2}{|c|}{ Levels I(0) } & \multicolumn{2}{|c|}{ First difference $\mathbf{I}(\mathbf{1})$} & \\
\hline & & & t-statistic & Break date & t-statistic & Break date & \\
\hline $\ln \mathrm{CO} 2$ & $-1.842214[0]$ & $-6.859844[0]^{* * *}$ & $-3.031649[0]$ & 1986 & $-8.087606[0]^{* * *}$ & 2000 & I(1) with break \\
\hline $\ln \mathrm{LifE}$ & $1.515890[4]$ & $-3.734049[5]^{* * *}$ & $-2.557130[3]$ & 1997 & $-5.385017[5]^{* * * *}$ & 1998 & I(1) with break \\
\hline $\ln$ LifEM & $1.135337[3]$ & $-3.566672[5]^{* *}$ & $-2.557675[3]$ & 1997 & $-5.460568[6]^{* * *}$ & 1999 & I(1) with break \\
\hline $\ln \mathrm{LifEF}$ & $1.355290[4]$ & $-3.497989[5]^{* *}$ & $-2.389715[3]$ & 1998 & $-5.393951[6]^{* * * *}$ & 1999 & I(1) with break \\
\hline $\ln \operatorname{Rgdpc}$ & $-0.043059[0]$ & $-5.388869[0]^{* * *}$ & $-2.250641[0]$ & 2003 & $-7.370283[0]^{* * *}$ & 2004 & I(1) with break \\
\hline $\ln \mathrm{VPet}$ & $-2.456715[0]$ & $-7.388426[0]^{* * *}$ & $-4.153401[0]$ & 2003 & $-8.290113[0]^{* * * *}$ & 1986 & I(1) with break \\
\hline $\ln$ Crdoilp & $-2.510039[0]$ & $-6.446855[0]^{* * *}$ & $-3.030107[0]$ & 1987 & $-7.659908[0]^{* * *}$ & 1981 & I(1) with break \\
\hline $\ln$ Pcrd & $-2.285337[1]$ & $-4.724064[0]^{* * * *}$ & $-2.823542[1]$ & 2006 & $-5.836209[2]^{* * * *}$ & 1990 & I(1) with break \\
\hline $\ln \mathrm{Dcrd}$ & $-2.639002[0]$ & $-5.207635[0]^{* * *}$ & $-3.308173[2]$ & 2006 & $-6.397791[0]^{* * * *}$ & 2010 & I(1) with break \\
\hline $\ln$ Popgrt & $-1.859284[3]$ & $-4.738240[2]^{* * *}$ & $-3.374165[4]$ & 1978 & $-8.682119[1]^{* * * *}$ & 1988 & I(1) with break \\
\hline $\ln \operatorname{Infrt}$ & $-3.706383[0]^{* * * *}$ & $-6.795280[1]^{* * *}$ & $-5.635724[1]^{* * * *}$ & 1995 & $-7.645655[0]^{* * * *}$ & 1990 & $\mathrm{I}(0)$ with break \\
\hline $\ln \operatorname{Trd}$ & $-2.525016[0]$ & $-8.019394[1]^{* * *}$ & $-3.563918[0]$ & 1986 & $-8.488151[0]^{* * * *}$ & 2001 & I(1) with break \\
\hline
\end{tabular}

\section{Results of ARDL co-integration test}

In ARDL bounds cointegration analysis, lag length selection test is considered very important as the F-statistic required for the implementation of the model is known to be sensitive to lag order. This first step test involves examining the sequential modified LR test statistic (LR), Final prediction error (FPE), Akaike information criterion (AIC), Schwarz information criterion (SIC) and Hannan-Quinn information criterion (HQ) for the selection of appropriate lag length. The implementation of this first step test shows that 3 is suggested by all the criteria as the appropriate lag length for the implementation of the ARDL bounds cointegration test for all the specifications. Following the suggestion of Lütkepohl (2006) in small sample analysis, this study uses Akaike Information Criterion (AIC) for selecting the optimal lag length.

Given the relatively small sample size of 44 observations (1971-2014) used in this study, the critical values for the evaluation of the null hypothesis are taken from Narayan (2005). Narayan (2005) computed two sets of critical values: lower bounds I(0) and upper bounds critical I(1) for sample sizes ranging from $T=30$ to 80 . The results of the co-integration test based on the ARDL-bounds testing method are presented in Table 3. The results indicate that the F-statistic is greater than the upper critical bound from Narayan (2005) at 1\% significant level for all the specifications of the ARDL models examined using restricted intercept and no trend. This study therefore rejects the null hypothesis of no cointegration among the variables. This shows that there is a longrun causal relationship between oil sector activities, environmental pollution, life expectancy at birth and other selected indicators of economic performance in Nigeria.

\section{Long-run and short-run estimates}

The estimates for all the specifications of Model 1 are presented in Table 4. The long-run coefficients in Panel B show that the coefficient of the oil export revenue $\ln \mathrm{VPet}$ is positive and statistically significant at $1 \%$ level in specifications 1 and 3 , and at $5 \%$ level in specification 2 . From the long-run coefficients, a $1 \%$ increase in the value 
of petroleum exports (oil revenue) significantly increases life expectancy at birth by $0.0714 \%$. Distinguishing between male and female populations, the estimates suggest that a $1 \%$ increase in the value of petroleum exports (oil revenue) contributes more to life expectancy of the male population $(0.1076 \%)$ than the female pollution $(0.0457 \%)$. The coefficient of $\mathrm{CO}_{2}$ emissions is negative and statistically significant in all the three specifications of Model 1. For the overall population, the coefficient which is significant at $1 \%$ level indicates that a one per cent increase in the level of $\mathrm{CO}_{2}$ emissions in the Nigerian economy would cause life expectancy at birth to decrease by $0.0438 \%$. Specifications LifEM (male population) and LifEF (female population) shows that a one per cent increase in the level of $\mathrm{CO} 2$ emissions in the economy affects the male population more $(-0.0596)$ than the female population $(-0.0262)$. The coefficient of GDP per capita is positive and statistically significant. Panel A of Table 4 shows that the short-run coefficient of the value of petroleum exports (oil revenue) is positive and statistically significant for the overall population at 5\% level. Overall the results in Table 4 show that the long-run effects of the value of petroleum exports (oil revenue) and $\mathrm{CO}_{2}$ emissions on life expectancy in Nigeria are stronger in the long run.

The results of Model 2 are presented in Table 5. Oil sector activities are captured using the average of daily crude oil production (oil production effect). The long-run estimates in Panel B show that an increase the production activities of the oil sector significantly decreases life expectancy in the country. The coefficient of -0.1276 which is statistically significant at $10 \%$ level for the overall population shows that a one per cent increase in crude oil production activities decreases life expectancy in the country by $0.1276 \%$. The results also suggest that the long-run influence of crude oil production activities (oil production effect) on life expectancy of the female population is statistically significant at $1 \%$ level. The coefficient of $\mathrm{CO}_{2}$ emissions is negative and statistically significant in all the specifications of Model 2, confirming the negative impact of an increase in the level of $\mathrm{CO}_{2}$ emissions on life expectancy in Nigeria as observed from the results of Model 1. It is also observed from the results in Pane A of Table 5 that the short-run effect of oil sector production activities on life expectancy of the female population in Nigeria is negative and statistically significant at 5\% level. The long-run and short-run estimates therefore suggest that oil sector production activities exert more influence on life expectancy of the female population in Nigeria.

Table 3. ARDL bounds cointegration test results

\begin{tabular}{|c|c|c|c|c|}
\hline Specifications & Break date & ARDL & F-statistic & Result \\
\hline 1. $\mathrm{F}_{\mathrm{LifE}}(\ln \mathrm{LifE} \mid \ln \mathrm{Rgdpc}, \ln \mathrm{CO} 2, \ln \mathrm{VPet}, \ln \mathrm{Pcrd}, \ln \mathrm{Infrt}, \ln$ Popgrt $)$ & 1997 & $(3,3,2,2,2,2,1)$ & $13.7792 * * *$ & Cointegration \\
\hline 2. $\mathrm{F}_{\mathrm{LifEM}}(\ln \mathrm{LifEM} \mid \ln \mathrm{Rgdpc}, \ln \mathrm{CO} 2, \ln \mathrm{VPet}, \ln \mathrm{Pcrd}, \ln \mathrm{Infrt}, \ln$ Popgrt $)$ & 1997 & $(3,3,2,2,2,2,1)$ & $11.0617 * * *$ & Cointegration \\
\hline 3. $\mathrm{F}_{\mathrm{LifF}}(\ln \mathrm{LifEF} \mid \ln \mathrm{Rgdpc}, \ln \mathrm{CO} 2, \ln \mathrm{VPet}, \ln \mathrm{Pcrd}, \ln \mathrm{Infrt}, \ln$ Popgrt $)$ & 1998 & $(3,3,2,3,2,1,1)$ & $14.6931 * * *$ & Cointegration \\
\hline 4. $\mathrm{F}_{\mathrm{LifE}}(\ln \mathrm{LifE} \mid \ln \mathrm{Rgdpc}, \ln \mathrm{CO} 2, \ln$ Crdoilp, $\ln \mathrm{Dcrd}, \ln \mathrm{Infrt}, \ln \mathrm{Trd})$ & 1997 & $(3,3,2,2,3,3,0)$ & $5.5262 * * *$ & Cointegration \\
\hline 5. $\mathrm{F}_{\mathrm{LifEM}}(\ln \mathrm{LifE} \mid \ln \mathrm{Rgdpc}, \ln \mathrm{CO} 2, \ln$ Crdoilp, $\ln \mathrm{Dcrd}, \ln \mathrm{Infrt}, \ln \mathrm{Trd})$ & 1997 & $(3,3,2,2,3,3,0)$ & $5.9579 * * *$ & Cointegration \\
\hline 6. $\mathrm{F}_{\mathrm{LifEF}}(\ln \mathrm{LifEF} \mid \ln \mathrm{Rgdpc}, \ln \mathrm{CO} 2, \ln$ Crdoilp, $\ln \mathrm{Dcrd}, \ln \mathrm{Infrt}, \ln \mathrm{Trd})$ & 1998 & $(3,3,2,1,3,3,1)$ & $13.7034 * * *$ & Cointegration \\
\hline 7. $\mathrm{F}_{\mathrm{CO} 2}(\ln \mathrm{CO} \mid \ln \mathrm{Rgdpc}, \ln \mathrm{LifE}, \ln \mathrm{VPet}, \ln \mathrm{Pcrd}, \ln$ Popgrt, $\ln \mathrm{InTrd})$ & 1986 & $(1,2,3,0,2,0,0)$ & $5.8217 * * *$ & Cointegration \\
\hline 8. $\mathrm{F}_{\mathrm{CO} 2}(\ln \mathrm{CO} 2 \mid \ln \mathrm{Rgdpc}, \ln \mathrm{LifEM}, \ln \mathrm{VPet}, \ln \mathrm{Pcrd}, \ln$ Popgrt, $\ln \mathrm{InTrd})$ & 1986 & $(1,3,3,0,2,0,0)$ & $6.1908 * * *$ & Cointegration \\
\hline \multicolumn{2}{|l|}{ Critical value bounds $(k=6)$} & $1 \%$ & $5 \%$ & $10 \%$ \\
\hline \multicolumn{2}{|l|}{$\mathbf{I}(\mathbf{0})$ bound } & 3.505 & 2.618 & 2.218 \\
\hline \multicolumn{2}{|l|}{ I(1) bound } & 5.121 & 3.863 & 3.314 \\
\hline
\end{tabular}

ARDL Models selected on Akaike info criterion (AIC). *** indicates Significance at $1 \%$ level. Source of critical value bounds: Narayan (2005) Appendix: Case II Restricted intercept and no trend for 
Table 4. ARDL estimates for Model 1

\begin{tabular}{|c|c|c|c|c|c|c|}
\hline \multirow{3}{*}{$\begin{array}{c}\text { Panel A } \\
\text { Variable }\end{array}$} & \multicolumn{6}{|c|}{ Short-run estimates } \\
\hline & \multicolumn{2}{|c|}{$\ln$ LifE } & \multicolumn{2}{|c|}{ lnLifEM } & \multicolumn{2}{|c|}{$\ln$ LifEF } \\
\hline & Coefficient & [t-Stat] & Coefficient & [t-Stat] & Coefficient & [t-Stat] \\
\hline $\operatorname{ECM}(-1)$ & $-0.00895^{* * *}$ & {$[-12.8029]$} & $-0.006 * * *$ & {$[-11.2961]$} & $-0.00927 * * *$ & {$[-13.1693]$} \\
\hline$\Delta \ln \operatorname{LifE}(-1)$ & $2.19941 * * *$ & [86.3745] & & & & \\
\hline$\Delta l n \operatorname{LifE}(-2)$ & $-1.32414 * * *$ & {$[-43.1240]$} & & & & \\
\hline$\Delta \ln \operatorname{LifEM}(-1)$ & & & $2.14898 * * *$ & [89.8460] & & \\
\hline$\Delta l n \operatorname{LifEM}(-2)$ & & & $-1.24116^{* * *}$ & {$[-45.1255]$} & & \\
\hline$\Delta l n \operatorname{LifEF}(-1)$ & & & & & $2.18366 * * *$ & [81.4109] \\
\hline$\Delta l n \operatorname{LifEF}(-2)$ & & & & & $-1.33928 * * *$ & [-40.7618] \\
\hline$\Delta l n \operatorname{Rgdpc}$ & 0.00002 & {$[0.0774]$} & -0.00034 & {$[-1.3105]$} & 0.00049 & [1.7912] \\
\hline$\Delta \ln \operatorname{Rgdpc}(-1)$ & $-0.0016^{* * *}$ & {$[-6.5170]$} & $-0.00135 * * *$ & {$[-5.3032]$} & $-0.00194 * * *$ & {$[-7.9689]$} \\
\hline$\Delta \ln \operatorname{Rgdpc}(-2)$ & $-0.00092 * * *$ & {$[-4.3493]$} & $-0.00119 * * *$ & {$[-5.4785]$} & $-0.0007 * * *$ & {$[-3.0775]$} \\
\hline$\Delta \operatorname{lnCO} 2$ & -0.00004 & {$[-0.5209]$} & 0.00007 & [0.8129] & 0.00008 & [1.0084] \\
\hline$\Delta \operatorname{lnCO} 2(-1)$ & $0.00021 * *$ & [2.6974] & $0.00024 * * *$ & [3.0099] & $0.00017^{* *}$ & [2.0110] \\
\hline$\Delta l n \mathrm{VPet}$ & $0.00011^{* *}$ & [2.0831] & 0.00003 & {$[0.6005]$} & $0.00009^{*}$ & [1.7421] \\
\hline$\Delta \ln \mathrm{VPet}(-1)$ & $-0.00019 * * *$ & {$[-4.5409]$} & $-0.00025^{* * *}$ & {$[-5.4566]$} & $-0.0001 * *$ & {$[-2.2016]$} \\
\hline$\Delta \ln \mathrm{VPet}(-2)$ & & & & & $0.00008^{*}$ & {$[1.8761]$} \\
\hline$\Delta \ln$ Pcrd & $-0.00021 * *$ & {$[-2.2487]$} & $-0.00064 * * *$ & {$[-6.8055]$} & 0.00001 & [0.1208] \\
\hline$\Delta \ln \operatorname{Pcrd}(-1)$ & $-0.00044 * * *$ & {$[-5.4592]$} & $-0.00029 * * *$ & {$[-3.3944]$} & $-0.00033^{* * *}$ & [-4.3163] \\
\hline$\Delta l n I n f r t$ & $0.00006^{* * *}$ & [3.0663] & 0.00003 & {$[1.2768]$} & $0.00007 * * *$ & [3.5260] \\
\hline$\Delta \ln \operatorname{Infrt}(-1)$ & $0.00007 * * *$ & [3.5274] & $0.00012 * * *$ & [5.5420] & & \\
\hline$\Delta \ln$ Popgrt & $0.00764 * * *$ & [11.7255] & $0.00837 * * *$ & [11.3105] & $0.00613^{* * *}$ & [10.0485] \\
\hline$\Delta \ln \mathrm{Brk} 97$ & 0.00006 & {$[1.0360]$} & 0.00002 & {$[0.3137]$} & & \\
\hline$\Delta \ln \mathrm{Brk} 98$ & & & & & -0.00003 & {$[-0.4369]$} \\
\hline Panel B & & & Long-r & un estimates & & \\
\hline Variable & Coefficient & t-Stat & Coefficient & t-Stat & Coefficient & t-Stat \\
\hline $\mathrm{C}$ & $2.1408^{* * *}$ & [8.2696] & $2.2965^{* * *}$ & {$[6.1960]$} & $1.6835 * * *$ & [5.0664] \\
\hline $\ln \operatorname{Rgdpc}$ & $0.1663^{* * *}$ & [3.5846] & 0.1151 & [1.5404] & $0.2528 * * *$ & [5.3633] \\
\hline $\ln \mathrm{CO} 2$ & $-0.0438 * * *$ & {$[-3.3025]$} & $-0.0596^{* *}$ & {$[-2.7076]$} & $-0.0262 *$ & {$[-1.9654]$} \\
\hline $\ln \mathrm{VPet}$ & $0.0714 * * *$ & [3.5289] & $0.1076^{* *}$ & [2.4086] & $0.0457 * * *$ & [3.0997] \\
\hline $\ln$ Pcrd & $0.0831^{* * *}$ & [5.5542] & $0.0698 * *$ & [2.4139] & $0.0912 * * *$ & [5.0013] \\
\hline $\ln$ Infrt & -0.0094 & {$[-1.3649]$} & -0.0281 & {$[-1.6682]$} & 0.0013 & {$[0.3077]$} \\
\hline lnPopgrt & 0.0069 & [0.0793] & 0.1176 & {$[0.6177]$} & -0.0552 & {$[-0.8611]$} \\
\hline Brk97 & 0.0054 & {$[0.4626]$} & 0.0009 & {$[0.0482]$} & & \\
\hline Brk98 & & & & & -0.0012 & {$[-0.0911]$} \\
\hline Panel C & & & Diagn & lostic tests & & \\
\hline Adjusted $\mathrm{R}^{2}$ & 0.9999 & & 0.9999 & & 0.9999 & \\
\hline D-W Statistic & 2.0139 & & 2.0981 & & 1.9613 & \\
\hline $\mathrm{SC}^{x^{2}}$ & 0.0650 & [0.7987] & 0.2557 & {$[0.6131]$} & 0.0001 & [0.9928] \\
\hline Het $x^{2}(1)$ & 0.9452 & [0.3309] & 0.1162 & [0.7332] & 0.0194 & [0.8893] \\
\hline RESET & 0.8974 & {$[0.3568$} & 2.0866 & {$[0.1668]$} & 1.0810 & [0.3130] \\
\hline JB & 0.3083 & {$[0.8572]$} & 0.1852 & [0.9115] & 1.4504 & [0.4842] \\
\hline
\end{tabular}

$*, * *$, and $* * *$ indicate significance at $10 \%, 5 \%$ and $1 \%$ respectively. t-statistics in [ ] and p-values in ( ); Adj R2 means adjusted R-squared; SC means Breusch-Godfrey serial correlation LM test; Het is the ARCH test for heteroscedasticity; RESET is the Ramsey RESET test; JB is theJarque-Bera Normality test 
Table 5. ARDL estimates for Model 2

\begin{tabular}{|c|c|c|c|c|c|c|}
\hline \multirow{3}{*}{$\begin{array}{c}\text { Panel A } \\
\text { Variable }\end{array}$} & \multicolumn{2}{|c|}{$\ln$ LifE } & \multicolumn{2}{|c|}{$\ln$ LifEM } & \multicolumn{2}{|c|}{$\ln$ LifEF } \\
\hline & \multicolumn{6}{|c|}{ Short-run estimates } \\
\hline & Coefficient & t-Statistic & Coefficient & t-Statistic & Coefficient & t-Statistic \\
\hline $\operatorname{ECM}(-1)$ & $-0.01054 * * *$ & {$[-8.5459]$} & $-0.0096 * * *$ & {$[-8.8210]$} & $-0.0162 * * *$ & {$[-12.8756]$} \\
\hline$\Delta \ln \operatorname{LifE}(-1)$ & $2.43521 * * *$ & [42.2057] & & & & \\
\hline$\Delta l n \operatorname{LifE}(-2)$ & $-1.5281 * * *$ & {$[-23.6345]$} & & & & \\
\hline$\Delta \ln \operatorname{LifEM}(-1)$ & & & $2.49034 * * *$ & {$[40.3552]$} & & \\
\hline$\Delta l n \operatorname{LifEM}(-2)$ & & & $-1.56279 * * *$ & {$[-23.1835]$} & & \\
\hline$\Delta l n \operatorname{LifEF}(-1)$ & & & & & $2.4693 * * *$ & {$[58.3620]$} \\
\hline$\Delta l n \operatorname{LifEF}(-2)$ & & & & & $-1.64432 * * *$ & {$[-31.6522]$} \\
\hline$\Delta \ln \operatorname{Rgdpc}$ & -0.00011 & {$[-0.1898]$} & -0.00065 & {$[-1.2583]$} & $0.00115^{* * *}$ & {$[2.8786]$} \\
\hline$\Delta \ln \operatorname{Rgdpc}(-1)$ & $-0.0024 * * *$ & {$[-5.1392]$} & $-0.00273 * * *$ & {$[-5.8942]$} & $-0.00259 * * *$ & {$[-8.7166]$} \\
\hline$\Delta \ln \operatorname{Rgdpc}(-2)$ & $-0.00096 * *$ & {$[-2.3626]$} & $-0.00115 * *$ & {$[-2.8286]$} & $-0.00073 * *$ & {$[-2.4323]$} \\
\hline$\Delta \operatorname{lnCO} 2$ & -0.00015 & {$[-1.0112]$} & -0.0002 & {$[-1.3286]$} & -0.00006 & {$[-0.5325]$} \\
\hline$\Delta \operatorname{lnCO} 2(-1)$ & $0.00036^{* *}$ & [2.4911] & $0.00029 * *$ & [2.0346] & $0.00036^{* * *}$ & [3.5183] \\
\hline$\Delta \ln$ Crdoilp & -0.00047 & {$[-1.5370]$} & -0.00022 & {$[-0.7302]$} & $-0.00057 * *$ & {$[-2.6454]$} \\
\hline$\Delta \ln$ Crdoilp $(-1)$ & $0.0005^{*}$ & {$[1.9325]$} & $0.00068 * *$ & {$[2.6620]$} & & \\
\hline$\Delta \ln \mathrm{Dcrd}$ & $0.00029 * *$ & [2.5952] & $0.00029 * *$ & [2.6133] & $0.00048 * * *$ & [5.4908] \\
\hline$\Delta \ln$ Dcrd $(-1)$ & $-0.00073 * * *$ & {$[-7.2795]$} & $-0.00081 * * *$ & {$[-7.7138]$} & $-0.00088 * * *$ & {$[-11.6511]$} \\
\hline$\Delta \ln \mathrm{Dcrd}(-2))$ & $-0.00067 * * *$ & {$[-7.1648]$} & $-0.00075 * * *$ & {$[-7.8107]$} & $-0.00072 * * *$ & {$[-10.6233]$} \\
\hline$\Delta \operatorname{lnInfrt}$ & $-0.00008 * *$ & {$[-2.1625]$} & $-0.00016^{* * *}$ & {$[-3.9734]$} & -0.00003 & {$[-1.3599]$} \\
\hline$\Delta \ln \operatorname{Infrt}(-1)$ & $0.00015 * * *$ & [4.0606] & $0.00023 * * *$ & {$[5.5851]$} & $0.0001 * * *$ & [3.6769] \\
\hline$\Delta \ln \operatorname{Infrt}(-2)$ & $0.00013 * * *$ & {$[3.2972]$} & $0.00015^{* * *}$ & [3.7759] & $0.00009 * * *$ & [3.2091] \\
\hline$\Delta \ln \mathrm{Trd}$ & $-0.00021 *$ & {$[-1.7952]$} & $-0.00024 * *$ & {$[-2.0398]$} & $-0.00029 * * *$ & {$[-3.6283]$} \\
\hline$\Delta \ln \mathrm{Brk} 97$ & -0.00014 & {$[-1.3436]$} & $-0.00024 * *$ & {$[-2.3551]$} & & \\
\hline$\Delta \ln \mathrm{Brk} 98$ & & & & & $0.00027 * * *$ & [3.6853] \\
\hline Panel B & \multicolumn{6}{|c|}{ Long-run estimates } \\
\hline Variable & Coefficient & t-Stat & Coefficient & t-Stat & Coefficient & t-Stat \\
\hline $\mathrm{C}$ & $2.5121 * * *$ & [5.1859] & $2.5707 * * *$ & {$[5.3690]$} & $2.1807 * * *$ & [9.8739] \\
\hline $\ln \mathrm{Rgdpc}$ & $0.3021 * * *$ & {$[6.8741]$} & $0.3069 * * *$ & {$[7.0251]$} & $0.3006 * * *$ & [12.5104] \\
\hline $\ln \mathrm{CO} 2$ & $-0.0674 * *$ & {$[-2.4549]$} & $-0.0784 * *$ & {$[-2.9980]$} & $-0.0346 * * *$ & {$[-2.9255]$} \\
\hline $\ln$ Crdoilp & $-0.1276^{*}$ & {$[-1.9341]$} & $-0.1426^{*}$ & {$[-1.9763]$} & $-0.0782 * * *$ & {$[-3.1981]$} \\
\hline $\ln$ Dcrd & $0.1020 * * *$ & [10.6247] & $0.1151 * * *$ & [11.0141] & $0.0905 * * *$ & [20.2187] \\
\hline $\ln$ Infrt & $-0.0261 *$ & {$[-1.9435]$} & $-0.0432 * *$ & {$[-2.5914]$} & -0.0077 & {$[-1.5954]$} \\
\hline $\ln \operatorname{Trd}$ & -0.0283 & {$[-1.5677]$} & -0.0274 & {$[-1.5127]$} & $-0.0304 * * *$ & {$[-2.9735]$} \\
\hline Brk97 & -0.0019 & {$[-0.1071]$} & -0.0137 & {$[-0.7001]$} & & \\
\hline Brk98 & & & & & 0.0171 & [1.8927] \\
\hline Panel C & \multicolumn{6}{|c|}{ Diagnostic tests } \\
\hline Adjusted $\mathrm{R}^{2}$ & 0.9999 & & 0.9999 & & 0.9999 & \\
\hline D-W Statistic & 1.9584 & & 1.8673 & & 2.0757 & \\
\hline $\mathrm{SC}^{x^{2}}$ & 0.0113 & {$[0.9154]$} & 0.1773 & {$[0.6737]$} & 0.4176 & {$[0.5181]$} \\
\hline $\operatorname{Het}^{x^{2}(1)}$ & 0.7166 & {$[0.3972]$} & 0.0373 & {$[0.8468]$} & 0.0273 & {$[0.8687]$} \\
\hline RESET & 0.8774 & {$[0.3628]$} & 1.2712 & {$[0.2762]$} & 0.4684 & {$[0.5030]$} \\
\hline JB & 0.5829 & {$[0.7472]$} & 0.5713 & {$[0.7515]$} & 0.2171 & {$[0.8971]$} \\
\hline
\end{tabular}

$*, * *$, and $* * *$ indicate significance at $10 \%, 5 \%$ and $1 \%$ respectively. t-statistics in [ ] and p-values in ( ); Adj $\mathrm{R}^{2}$ means Adjusted R-squared; SC means Breusch-Godfrey serial correlation LM test; Het is the $\mathrm{ARCH}$ test for heteroscedasticity; RESET is the Ramsey RESET test; JB is the Jarque-Bera Normality test 
The estimates of Model 3 are presented in Table 6 . The dependent variable is $\mathrm{CO}_{2}$ emissions. This model examines the influence of oil sector activities and life expectancy on $\mathrm{CO}_{2}$ emissions in Nigeria.

Table 6. ARDL estimates for Model 3

\begin{tabular}{|c|c|c|c|c|}
\hline \multirow{3}{*}{\begin{tabular}{|l} 
Panel A \\
Variable
\end{tabular}} & \multicolumn{2}{|c|}{ Specification 1} & \multicolumn{2}{|c|}{ Specification 2} \\
\hline & \multicolumn{4}{|c|}{ Short-run estimates } \\
\hline & Coefficient & t-Statistic & Coefficient & t-Statistic \\
\hline $\operatorname{ECM}(-1)$ & $-0.5496 * * *$ & {$[-5.0580]$} & $-0.5726 * * *$ & {$[-5.1901]$} \\
\hline$\Delta \ln \operatorname{Rgdpc}$ & 0.3527 & {$[0.9031]$} & $0.7151 *$ & [1.7929] \\
\hline$\Delta \ln \operatorname{Rgdpc}(-1)$ & $-1.6256 * * *$ & {$[-4.3010]$} & $-1.2373 * * *$ & {$[-3.2567]$} \\
\hline$\Delta \ln \operatorname{Rgdpc}(-2)$ & & & $0.6689 * *$ & {$[2.1276]$} \\
\hline$\Delta \ln \mathrm{LifE}$ & -58.6223 & {$[-0.5934]$} & & \\
\hline$\Delta \ln \operatorname{LifE}(-1)$ & $389.8753^{*}$ & {$[1.7729]$} & & \\
\hline$\Delta \ln \operatorname{LifE}(-2)$ & $-367.2620 * *$ & {$[-2.8167]$} & & \\
\hline$\Delta \ln \mathrm{LifEM}$ & & & 145.2533 & {$[1.4735]$} \\
\hline$\Delta \ln \operatorname{LifEM}(-1)$ & & & 12.5453 & {$[0.0571]$} \\
\hline$\Delta \ln \operatorname{LifEM}(-2)$ & & & -191.8012 & {$[-1.4660]$} \\
\hline$\Delta \ln \mathrm{VPet}$ & $0.3960 * * *$ & {$[5.7580]$} & $0.4434 * * *$ & {$[6.3971]$} \\
\hline$\Delta \ln \mathrm{Pcrd}$ & $0.5397 * * *$ & {$[3.8675]$} & $0.7801 * * *$ & {$[4.8282]$} \\
\hline$\Delta \ln \operatorname{Pcrd}(-1)$ & $-0.5221 * * *$ & {$[-4.0170]$} & $-0.5326 * * *$ & {$[-4.0652]$} \\
\hline$\Delta \ln$ Popgrt & -0.8893 & {$[-0.9491]$} & $-1.6198 *$ & {$[-1.7329]$} \\
\hline$\Delta \ln \operatorname{Trd}$ & $-0.1932 * *$ & {$[-2.0600]$} & $-0.1727 *$ & {$[-1.8894]$} \\
\hline$\Delta \mathrm{Brk} 86$ & $0.4276 * * *$ & {$[4.1478]$} & $0.4129 * * *$ & {$[4.0859]$} \\
\hline Panel B & \multicolumn{4}{|c|}{ Long-run estimates } \\
\hline Variable & Coefficient & t-Statistic & Coefficient & t-Statistic \\
\hline $\mathrm{C}$ & $40.2176^{* * *}$ & {$[4.7902]$} & $41.5316^{* * *}$ & {$[5.5126]$} \\
\hline $\ln \operatorname{Rgdpc}$ & 1.8636 & {$[1.1692]$} & 1.9177 & {$[1.5217]$} \\
\hline $\ln$ LifE & $-14.9700 * * *$ & {$[-3.2225]$} & & \\
\hline $\ln \mathrm{LifEM}$ & & & $-15.6707 * * *$ & {$[-4.2039]$} \\
\hline $\ln \mathrm{VPet}$ & $0.6226^{* *}$ & {$[2.8126]$} & $0.6508 * * *$ & {$[3.2034]$} \\
\hline $\ln$ Pcrd & $1.3532 * *$ & {$[2.7447]$} & $1.6521 * * *$ & [3.6544] \\
\hline lnPopgrt & -1.8287 & {$[-1.2336]$} & -2.3382 & {$[-1.6742]$} \\
\hline $\ln \operatorname{Trd}$ & -0.2735 & {$[-1.4243]$} & -0.2007 & {$[-1.0920]$} \\
\hline Panel C & \multicolumn{4}{|c|}{ Diagnostic tests } \\
\hline Adjusted $\mathrm{R}^{2}$ & 0.8623 & & 0.8659 & \\
\hline D-W Statistic & 1.9645 & & 2.1762 & \\
\hline $\mathrm{SC}^{x^{2}}$ & 0.0001 & [0.9996] & 0.6645 & {$[0.4150]$} \\
\hline $\operatorname{Het}^{x^{2}(1)}$ & 0.6170 & {$[0.4322]$} & 0.0069 & [0.9337] \\
\hline RESET & 1.5116 & {$[0.2308]$} & 2.3541 & {$[0.1386]$} \\
\hline JB & 0.7992 & {$[0.6706]$} & 0.9215 & {$[0.6308]$} \\
\hline
\end{tabular}

$*, * *$, and $* * *$ indicate significance at $10 \%, 5 \%$ and $1 \%$ respectively. t-statistics in [ ] and p-values in ( ); Adj $\mathrm{R}^{2}$ means Adjusted R-squared; SC means Breusch-Godfrey serial correlation LM test; Het is the $\mathrm{ARCH}$ test for heteroscedasticity; RESET is the Ramsey RESET test; JB is the Jarque-Bera Normality test 
The long-run estimates in Panel B show that the coefficient of the oil income $\ln$ VPet is positive and statistically significant at $5 \%$ level in specifications 1 , and at $1 \%$ level in specification 2. From the long-run coefficients, a one per cent increase in the value of petroleum exports (oil revenue) significantly increases $\mathrm{CO}_{2}$ emissions in Nigeria by $0.6226 \%$ in the long-run. The long-run estimates also suggest that a significant negative relationship exists between life expectancy and $\mathrm{CO}_{2}$ emissions in Nigeria. The short-run estimates in Panel A show that a one per cent increase in petroleum export (oil revenue) produces over $0.3960 \%$ increase in $\mathrm{CO}_{2}$ emissions in Nigeria in the short-run. It is therefore evident from the results in Table 6 that oil export revenue contributes significantly to environmental pollution in the long-run as well as in the short-run.

The coefficient of ECM (-1) in all the specifications of Model 1, 2 and 3 is negative and significant at $1 \%$ level indicating that the adjustment of variables towards long-run dynamics is achieved. The diagnostic test results in Panel $\mathrm{C}$ of Tables 4, 5 and 6 show that there is no evidence of serial correlation, heteroscedasticity and functional form misspecification in each of the ARDL models specified. Figures 5-12 show the cumulative sum of recursive residuals (CUSUM) and the cumulative sum of squares (CUSUMSQ) stability test results for each of the ARDL specifications. The CUSUM and CUSUMSQ are all within the critical boundaries for the 5\% significance level indicating that the coefficients of the ARDL model in each of the specifications are stable.

\section{Discussion of results and policy implications}

The schematic view of the results of this empirical study is presented in Figure 13.

The positive relationship between the value of petroleum export and life expectancy in Nigeria suggests the dependence of health care expenditure, quality of education, employment opportunities, access to portable drinking water and other socio-economic drivers of life expectancy on oil income. This result is consistent with the findings of Bader and Ganguli (2019) for the Gulf Cooperation Council (GCC) countries. While oil export provides the income required to improve life expectancy in the country, it also generates conditions that accelerate environmental pollution in the economy. This shows that income from oil export significantly generates economic activities in the energy-intensive sectors and rapid accumulation of energy-using technologies in the economy. It is therefore expected that economic diversification policies in Nigeria would incorporate strategies encouraging firms in energy energy-intensive sectors including oil and gas firms to adopt advanced technologies that minimize environmental pollution. The income from petroleum exports could be used in the development of renewable energy sources in the economy. The development of solar and wind energy sources could increase access to clean forms of energy and lessen the level of $\mathrm{CO}_{2}$ emissions, which threaten environmental quality and reduce life expectancy of Nigerians.

The significant negative relationship between crude oil production and life expectancy indicates that an increase in the production activities of the oil sector creates environmental conditions considered direct risk to human health (Perera, 2018). While the threat of oil sector activities on environmental quality in Nigeria has been widely recognized (see Ologunorisa, 2001; Ugochukwu and Ertel, 2008; Audu et al., 2016), this study documents that the deteriorating environment is responsible for many adverse effects on health and well-being of Nigerians and therefore suggests that health policies 
targeting improvement in life expectancy will have to incorporate sound environmental measures aimed at reducing $\mathrm{CO} 2$ emissions from gas flaring in Nigeria's oil and gas industry. Considering gender differences in life expectancy in Nigeria, the results show that while a one per cent increase in the level of $\mathrm{CO}_{2}$ emissions in the economy affects the life expectancy of the male population more than the female population, crude oil production activities of the oil sector have significant negative short-run and long-run effects on life expectancy of the female population in Nigeria. This empirical result highlights the complexity of the environmental impact of oil resource on life expectancy in Nigeria.

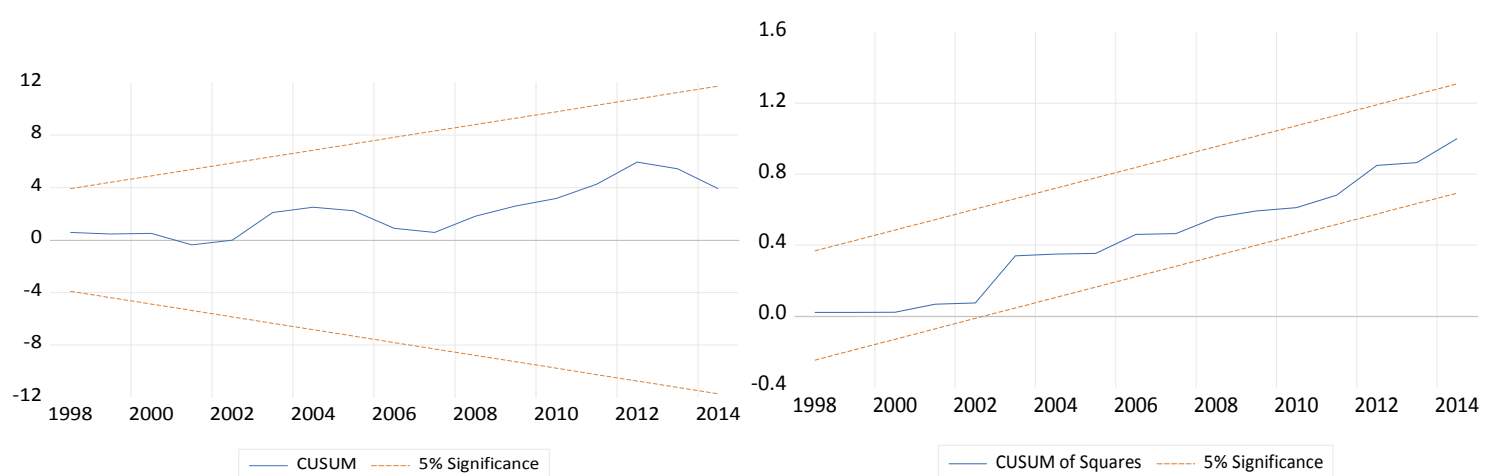

Figure 5. CUSUM and CUSUM of squares (Model 1 specification lnLifE)

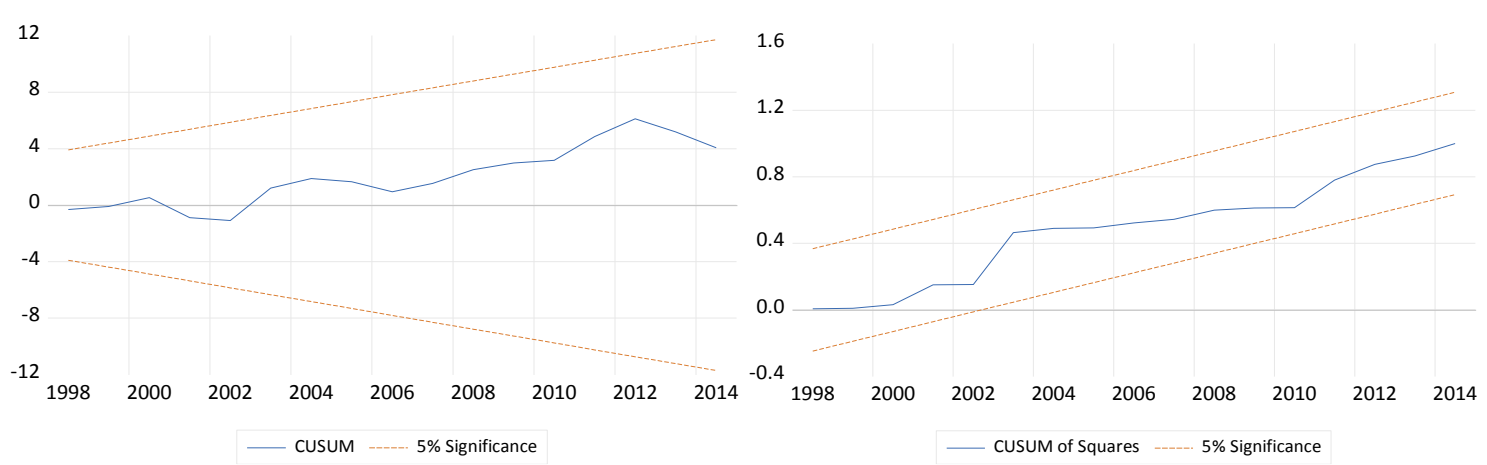

Figure 6. CUSUM and CUSUM of squares (Model 1 specification lnLifEM)

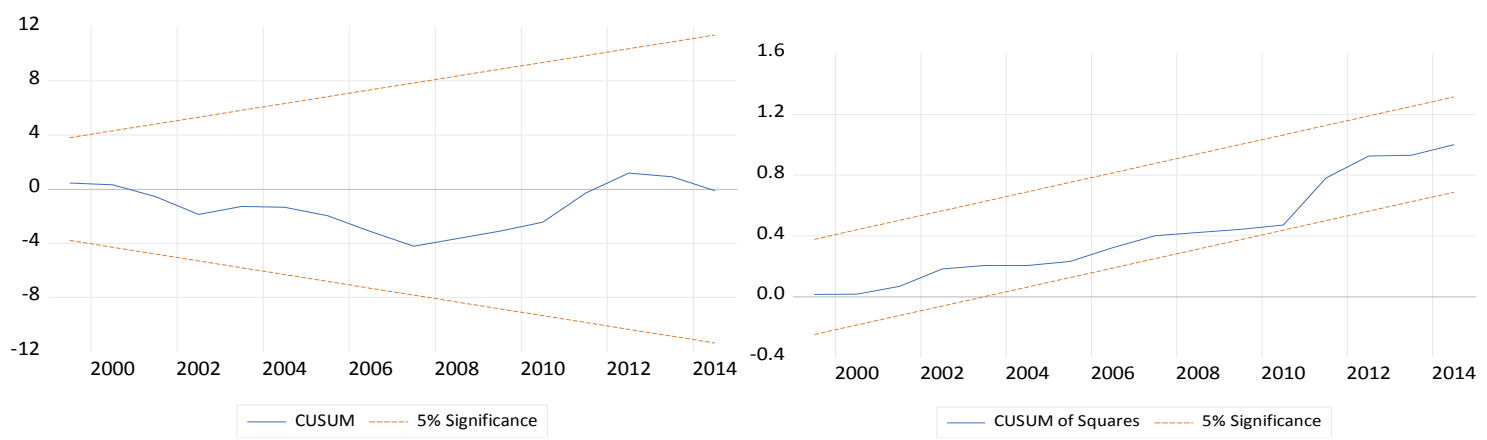

Figure 7. CUSUM and CUSUM of squares (Model 1 specification lnLifEF) 


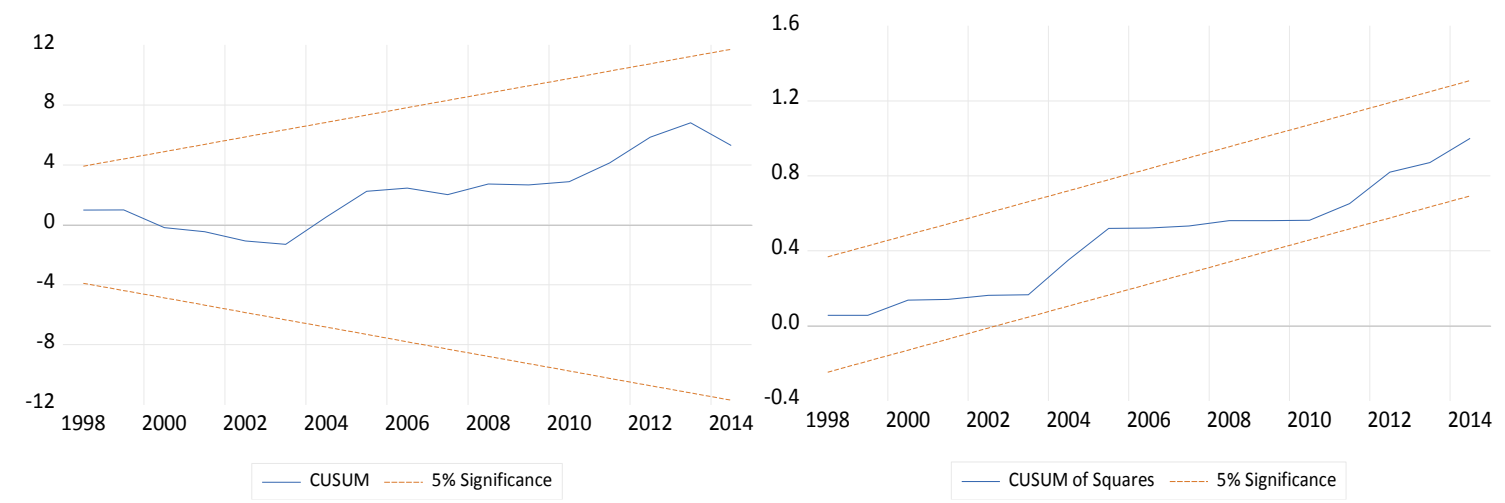

Figure 8. CUSUM and CUSUM of squares (Model 2 specification lnLifE)

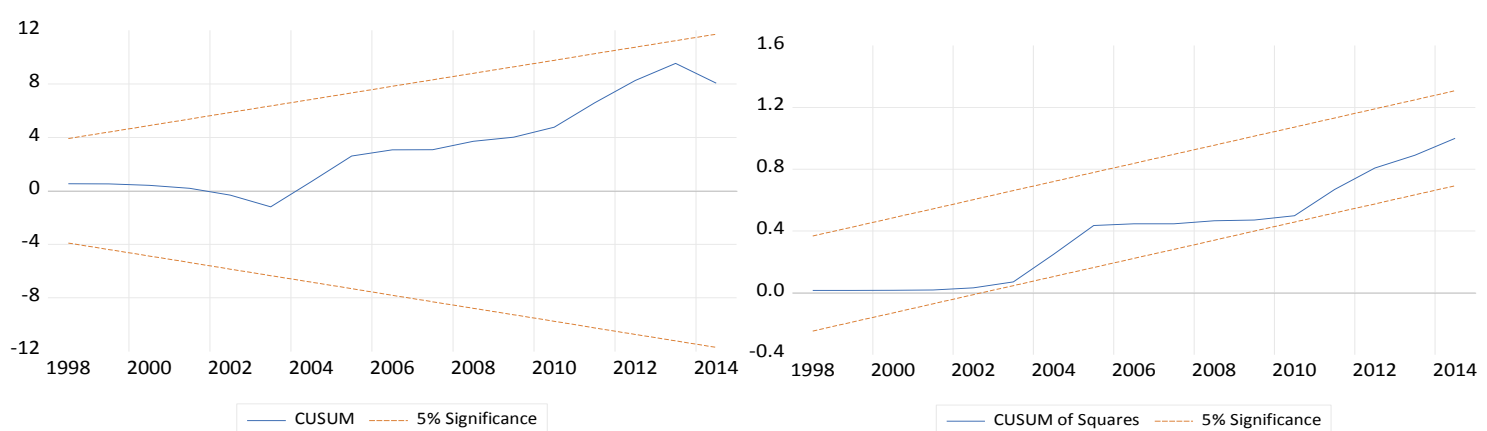

Figure 9. CUSUM and CUSUM of squares (Model 2 specification InLifEM)

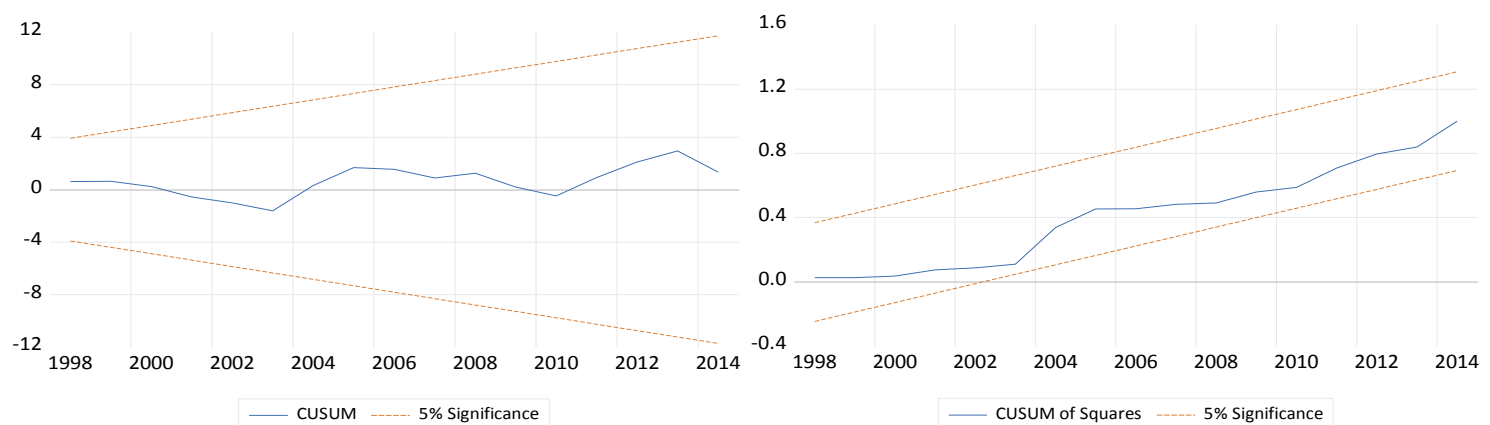

Figure 10. CUSUM and CUSUM of squares (Model 3 specification lnLifEF)

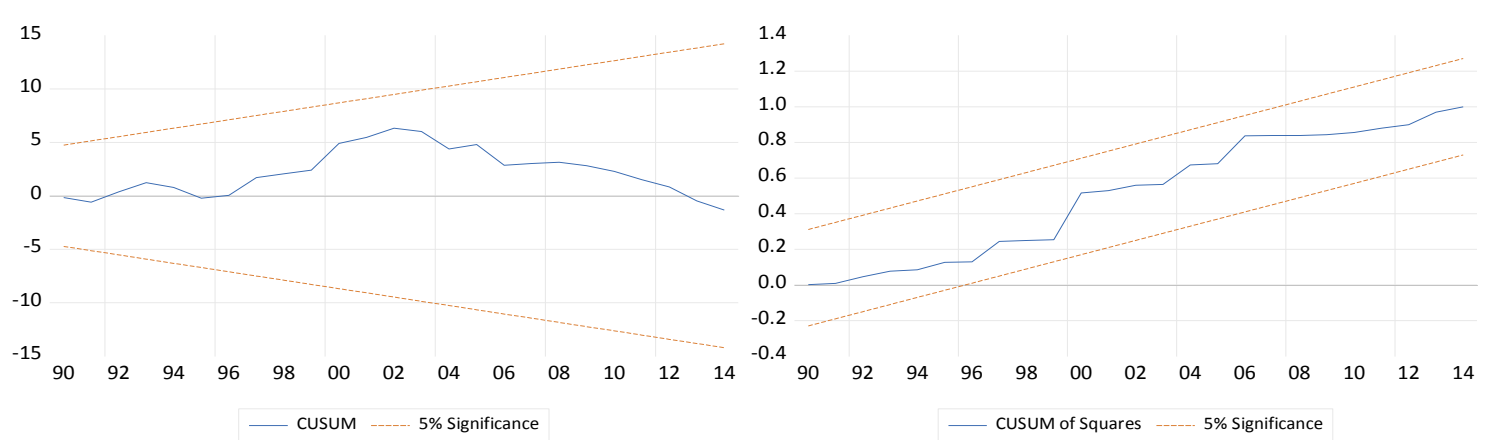

Figure 11. CUSUM and CUSUM of squares (Model 3 specification 1)

APPLIED ECOLOGY AND ENVIRONMENTAL RESEARCH 17(5):11143-11162.

http://www.aloki.hu • ISSN 15891623 (Print) • ISSN 17850037 (Online)

DOI: http://dx.doi.org/10.15666/aeer/1705_1114311162

(c) 2019, ALÖKI Kft., Budapest, Hungary 


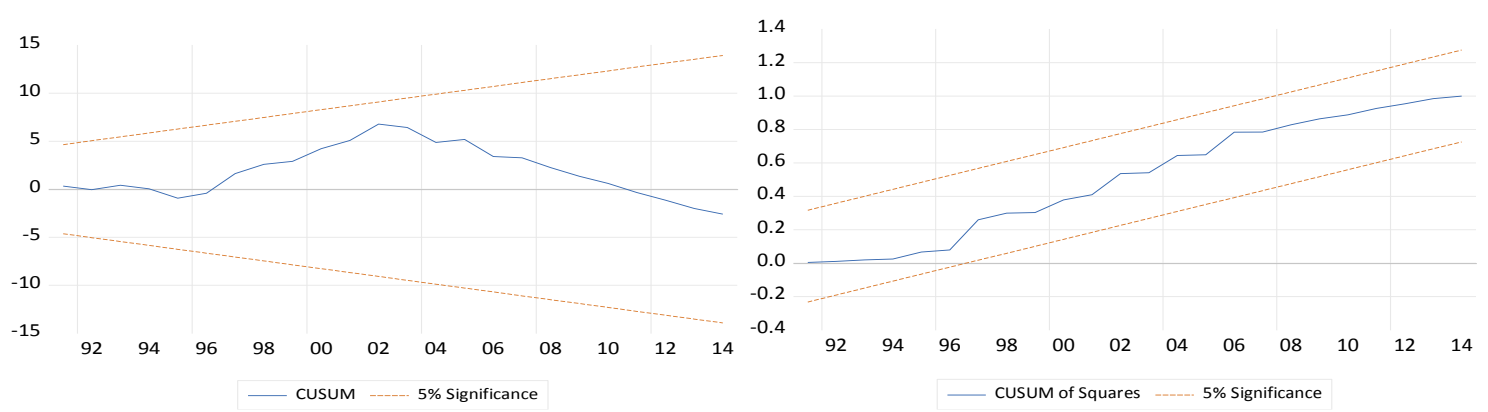

Figure 12. CUSUM and CUSUM of squares (Model 3 specification 2)

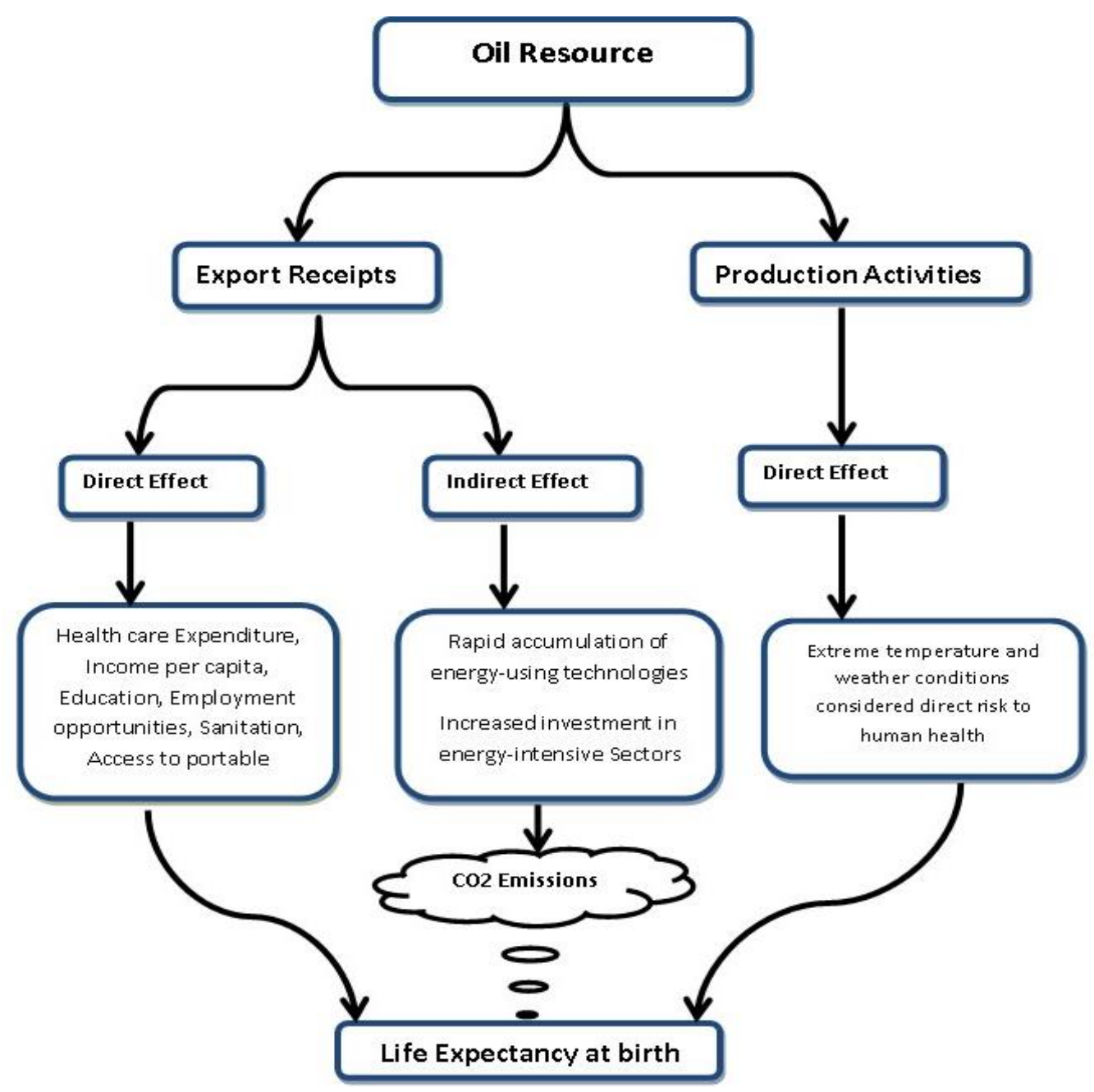

Figure 13. Relationship between oil resource, $\mathrm{CO}_{2}$ emissions and life expectancy in Nigeria

From the above discussion, the health implications of the activities of the oil and gas firms in Nigeria cannot be neglected. The activities of the oil and gas sector in Nigeria generate conditions that harm the health of the people through carbon dioxide $\left(\mathrm{CO}_{2}\right)$ emissions. One of these conditions that require urgent attention is the amount of gas flared from oil and gas activities in the country. Nigeria which began the production of crude oil in 1958 still lacked sufficient infrastructure and policy measures to reduce gas 
flaring, which is the most significant contributor of $\mathrm{CO} 2$ emission from oil and gas activities in Nigeria (Anomohanran, 2012). It may be necessary for the Nigerian government to design policy measures aimed at reducing gas flaring from the activities of oil and gas firms. Oil and gas firms operating in Nigeria have attempted to implement measures aimed at reducing gas flaring in time past. However, it is not certain if any of these efforts yielded significant level of reduction in the amount of gas flared yearly from oil and gas activities as these efforts were either not completed or facilities vandalised (Anomohanran, 2012). The schematic view of the results of this empirical study presented in Figure 13 therefore highlights the urgent need for policy measures to consider the environmental consequences of the dependence of the economy on oil resource and its implications on health condition, well-being and quality of life of Nigerians, if the country must experience significant improvement in life expectancy.

\section{Conclusion}

This study examined the dynamic relationship between oil sector activities, environmental pollution and life expectancy in Nigeria over the period 1971 to 2014. The long-run relationship among the variables is examined using ARDL bounds testing approach to cointegration. The results provide evidence of cointegration between the variables with the incorporation of the presence of a structural break observed in the series. The ARDL estimates suggest (i) a positive relationship between oil export revenue and life expectancy (ii) a positive relationship between oil export revenue and $\mathrm{CO}_{2}$ emissions (iii) a negative relationship between crude oil production activities and life expectancy, and (iv) a negative relationship between $\mathrm{CO}_{2}$ emissions and life expectancy. To further the understanding of the impacts of oil production activities and $\mathrm{CO}_{2}$ emissions on life expectancy in Nigeria, gender differences in life expectancy in Nigeria was considered. The results show that (i) a one per cent increase in the level of $\mathrm{CO}_{2}$ emissions in the economy affects the life expectancy of the male population more than the female population (ii) a one per cent increase in the value of petroleum exports (oil revenue) contributes more to life expectancy of the male population than the female pollution, and (iii) strong empirical evidence that crude oil production activities of the oil sector have significant short-run and long-run effects on life expectancy of the female population in Nigeria. Overall the results show that the impact of $\mathrm{CO}_{2}$ emissions on life expectancy in Nigeria is stronger in the long-run.

This study provides empirical evidence to support the urgent need for health policy measures in Nigeria to incorporate effective strategies for mitigation and adaptation meant to reduce the impact of the increasing role of the oil sector on health condition, wellbeing of the people and the overall goal of improving life expectancy in Nigeria.

\section{REFERENCES}

[1] Abbas, F., Awan, H. S. (2018): What determines health status of population in Pakistan? - Social Indicators Research 139: 1-23.

[2] Alam, M. S., Shahbaz, M., Paramati, S. R. (2016): The role of financial development and economic misery on life expectancy: evidence from post reforms in India. - Social Indicators Research 128: 481-497. DOI 10.1007/s11205-015-1040-4.

[3] Anomohanran, O. (2012): Determination of greenhouse gas emission resulting from gas flaring activities in Nigeria. - Energy Policy 45: 666-670. 
[4] Audu, A., Jimoh, A., Abdulkareem, S. A., Onyeji, L. (2016): Economics and environmental impacts of oil exploration and exploitation in Nigeria. - Energy Sources, Part B: Economics, Planning and Policy 11: 251-257. DOI: 10.1080/15567249.2011.627411.

[5] Bader, Y., Ganguli, S. (2019): Analysis of the association between economic growth, environmental quality and health standards in the Gulf Cooperation Council during 19802012. - Management of Environmental Quality: An International Journal. https://doi.org/10.1108/ MEQ-03-2018-0061.

[6] Barlow, R., Vissandjée, B. (1999): Determinants of national life expectancy. - Canadian Journal of Development Studies 20: 9-29. DOI: 10.1080/02255189.1999.9668787.

[7] Bergh, A., Nilsson, T. (2010): Good for living? On the relationship between globalization and life expectancy. - World Development 38(9): 1191-1203.

[8] Bezirtzoglou, C., Dekas, K., Charvalos, E. (2011): Climate changes, environment and infection: facts, scenarios and growing awareness from the public health community within Europe. - Anaerobe 17: 337-340.

[9] Chaabouni, S., Zghidi, N., Mbarek, M. B. (2016): On the causal dynamics between $\mathrm{CO}_{2}$ emissions, health expenditures and economic growth. - Sustainable Cities and Society 22: 184-191.

[10] Franchini, M., Mannucci, P. M. (2015): Impact on human health of climate changes. European Journal of Internal Medicine 26: 1-5.

[11] Hertz, E., Hebert, J. R., Landon, J. (1994): Social and environmental factors and life expectancy, infant mortality, and maternal mortality rates: results of cross-national comparison. - Social Science and Medicine 39: 105-I 14.

[12] Kim, J. I., Kim, G. (2016): Country-level socioeconomic indicators associated with healthy life expectancy: income, urbanization, schooling, and internet users: 2000-2012. Social Indicators Research 129: 391-402. DOI 10.1007/s11205-015-1107-2.

[13] Liang, L., Gong, P. (2017): Climate change and human infectious diseases: a synthesis of research findings from global and spatio-temporal perspectives. - Environment International 103: 99-108.

[14] Lu, Z., Chen, H., Hao, Y., Wang, J., Song, X., Mok, T. (2017): The dynamic relationship between environmental pollution, economic development and public health: evidence from China. - Journal of Cleaner Production 166: 134-147.

[15] Lütkepohl, H. (2006): Structural Vector Autoregressive Analysis for Cointegrated Variables. - In: Hübler, O., Frohn, J. (eds.) Modern Econometric Analysis. Springer, Berlin, pp. 73-86.

[16] Mariani, F., Perez-Barahona, A., Raffin, N. (2010): Life expectancy and the environment. - Journal of Economic Dynamics \& Control 34: 798-815.

[17] Marsh, K, Ganz, G. L., Hsu, J., Strandberg-Larsen, M., Gonzalez, R. P., Lund, N. (2016): Expanding health technology assessments to include effects on the environment. -Value in Health 19: 249 - 254.

[18] Murthy, V. N. R., Okunade, A. A. (2016): Determinants of U.S. health expenditure: Evidence from autoregressive distributed lag (ARDL) approach to cointegration. Economic Modelling 59: 67-73.

[19] Narayan, P. K. (2005): The saving and investment nexus for China: evidence from cointegration tests. $\quad-$ Applied Economics 37: 1979-1990. https://doi.org/10.1080/00036840500278103.

[20] Ologunorisa, T. E. (2001): A review of the effects of gas flaring on the Niger Delta environment. - The International Journal of Sustainable Development \& World Ecology 8: 249-255. DOI: 10.1080/13504500109470082.

[21] Pautrel, X. (2009): Pollution and life expectancy: how environmental policy can promote growth. - Ecological Economics 68: 1040-1051. 
[22] Perera, F. (2018): Pollution from fossil-fuel combustion is the leading environmental threat to global pediatric health and equity: solutions exist. - International Journal of Environmental Research and Public Health 15: 16. DOI: 10.3390/ijerph15010016.

[23] Perron, P. (2006): Dealing with Structural Breaks. - In: Hassani, H., Mills, T. C., Patterson, K. (eds.) Palgrave Handbook of Econometrics (1st Ed.) Palgrave Macmillan, UK.

[24] Pesaran, M. H., Shin, Y., Smith, R. J. (2001): Bounds testing approaches to the analysis of long run relationships. - Journal of Applied Econometric 16: 289-326. https://doi.org/10.1002/jae.616.

[25] Qureshi, M. I., Rasli, A. M., Awan, U., Ma, J., Ali, G., Faridullah, Alam, A., Sajjad, F., Zaman, K. (2015): Environment and air pollution: health services bequeath to grotesque menace. - Environmental Science and Pollution Research 22: 3467-3476. DOI 10.1007/s11356-014-3584-2.

[26] Sede, P. I., Ohemeng, W. (2015): Socio-economic determinants of life expectancy in Nigeria (1980-2011). - Health Economics Review 5. DOI 10.1186/s13561-014-0037-z.

[27] Shahbaz, M., Loganathan, N., Mujahid, N., Ali, A., Nawaz, A. (2016): Determinants of life expectancy and its prospects under the role of economic misery: a case of Pakistan. Social Indicators Research 126: 1299-1316 DOI 10.1007/s11205-015-0927-4.

[28] Tai, M.; Chao, C., Hu, S. (2015): Pollution, health and economic growth. - North American Journal of Economics and Finance 32: 155-161.

[29] Ugochukwu, C. N. C., Ertel, J. (2008): Negative impacts of oil exploration on biodiversity management in the Niger De area of Nigeria. - Impact Assessment and Project Appraisal 26: 139-147.

[30] Vogelsang, T. J., Perron, P. (1998): Additional test for unit root allowing for a break in the trend function at an unknown time. - International Economic Review 39: 1073-1100.

[31] Wu, C. (2017): Human capital, life expectancy, and the environment. - The Journal of International Trade \& Economic Development 26: 885-906. DOI: 10.1080/09638199.2017.1314543.

[32] Wu, X., Lu, Y., Zhou, S., Chen, F., Xu, B. (2016): Impact of climate change on human infectious diseases: empirical evidence and human adaptation. - Environment International 86: 14-23. 